\title{
The Great Mosque of Tlemcen and the Dome of its Maqșūra
}

\author{
La mezquita mayor de Tremecén y la cúpula de \\ su maqșüra
}

\author{
Antonio Almagro \\ Escuela de Estudios Árabes, CSIC, Granada, España
}

The aim of this article is to study some aspects of the Great Mosque of Tlemcen based on a planimetrical survey that has recently been carried out on its most outstanding features, particularly the area of the mihrāb and the maqșüra. It provides observations on this significant monument from Almoravid times that relate to its analysis by means of drawings. In spite of the fact that it is considered to be one of the most emblematic buildings of Western Islamic art of the 12th Century, only general ground plans have been published up until now, mostly schematic ones, and a few detailed drawings. The plans that we are publishing enable us to comprehend to a greater extent this remarkable building that is set out in comparison with other examples, and especially with regard to the vaults of intertwined arches.

Key words: Mosque; Almoravid; Interwined Arches; Openwork Dome; Geometrical Analysis.
El presente artículo tiene como objeto estudiar algunos aspectos de la mezquita mayor de Tremecén basándonos en un levantamiento planimétrico realizado recientemente de sus elementos más singulares, en especial del área del mihrāa y la maqșūra, aportando algunas observaciones sobre este importante monumento de época almorávide que se desprenden de su análisis a través de los dibujos. Pese a ser considerada una de las construcciones más emblemáticas del arte islámico occidental del siglo XII, nunca se han publicado hasta ahora más que plantas generales, casi todas esquemáticas, y algunos dibujos de detalles. Los planos que publicamos permiten una mejor comprensión de esta obra singular que se pone en relación con otros ejemplos y de un modo especial a través de las bóvedas de arcos entrecruzados.

Palabras clave: mezquita; almorávides; arcos entrecruzados; bóveda calada; trazados reguladores.

The dome covering the space adjoining the mihrāb of the great mosque of Tlemcen together with its adornments (Fig. 1), have always been considered as one of the most outstanding works of art of the Almoravids. In spite of having received continuous citations and analyses of a diverse nature, it is surprising that no complete planimetry has ever been published on this area. As it has been possible to carry it out, we 
believe for the first time, we think it is appropriate to publish it together with relevant architectural analysis. We consider that this will provide more extensive knowledge about this unique piece of Islamic art.

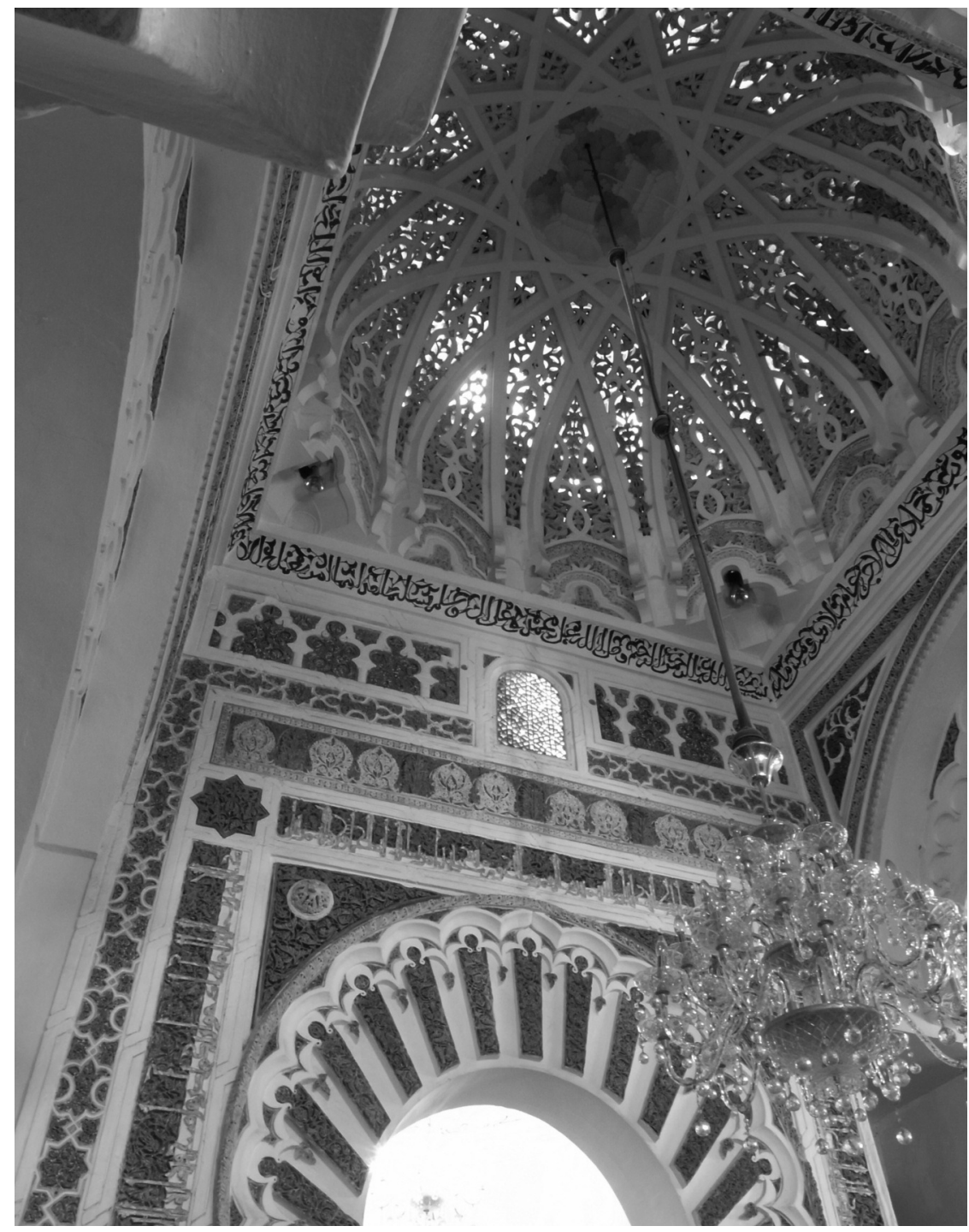

Figure 1. Space in front of the mihrāb of the Great Mosque of Tlemcen (A. Almagro). 
Since the French researchers from colonial times brought us knowledge of it, there have been numerous points of reference on this work of art by scholars and researchers. Particularly worth emphasizing is the collection of drawings by Georges Marçais of the dome and adornments of the mihra $b$ and the mosque. This is in the album on Muslim Art in Algeria, ${ }^{1}$ and forms a repertoire of the ornamental elements which are undoubtedly of a high quality and are presented in a splendid large size edition; however, there is a lack of specifically architectural documentation. In particular there is an absence of sections that show the true form and dimensions of the space and the constructive solutions.

\section{Historiography}

It was in the middle of the 19th century when news of the great mosque of Tlemcen began to reach Europe, at the time of the French occupation of Algeria. At the same time as the French troops were establishing control over the country, travellers, draftsmen and military engineers began to produce reports and graphic drawings that constitute the first modern information of the Tlemcen monuments. ${ }^{2}$ At a date close to the arrival of the French in the city there were already two excellent drawings of the prayer room and the mosque courtyard. ${ }^{3}$ The Tlemcen monuments immediately attracted the attention of the colonial authorities who from an early stage established protective measures for them, almost coinciding with their protection of the monuments of the French home land. In 1875 the most significant monuments of this Algerian city, such as the great mosque and the Manșūra minaret, were declared "Historical Monuments." Simultaneously we have news of the intervention by the restorers who produced the first outstanding planimetrical documents and interventions, such as the consolidation of the minaret of the mosque of Manșura, done by the architect E. Duthoit. ${ }^{4} \mathrm{He}$ also carried out the first known plan of the

1 Marçais, Album de pierre, plâtre et bois sculptés.

${ }^{2}$ Charpentier and Terrasse, L'image de Tlemcen dans les archives françaises.

${ }_{3}^{3}$ Berbrugger, Algérie historique, pittoresque et monumentale, reproduced in Charpentier and Terrasse, L'image de Tlemcen, p. 85.

${ }^{4}$ Charpentier and Terrasse, L'image de Tlemcen, p. 105. 
mosque built in $1872,{ }^{5}$ as well as some detailed drawings of its decoration, and that of the closing fence of the maqșura that was still in place.

The first scientific studies on the Tlemcen mosque were thanks to William and Georges Marçais ${ }^{6}$ and subsequently to the latter who published in 1909 in his album of Muslim art in Algeria ${ }^{7}$ a splendid collection of drawings probably based on the drawings by Duthoit. Later, in his Manuel d'Art Musulman ${ }^{8}$ and further to that in his book on L'Architecture Musulmane d'Occident ${ }^{9}$ he gives us the essential data for interpreting the building and the history of its construction. These have only received slight clarifications at a later date by L. Golvin, ${ }^{10} \mathrm{R}$. Bourouiba, ${ }^{11} \mathrm{M}$. Terrasse ${ }^{12}$ and A. Charpentier. ${ }^{13}$

The mosque must have been built at the time of the foundation of Tagrart, a new town that was an extension of the ancient Agadir, founded by the Idrīsids, by Yūsuf b. Tashufin in about 1082 and given enriched decoration by his son and successor 'Alī b. Yūsuf in 1136 . We should bear in mind that there may have been Almohad intervention, which we shall mention later on. Finally, the construction of the minaret in about $1236^{14}$ may be attributed to the first ${ }^{~} A b d$ al-Wādid emir, Yaghmorasan, and probably the courtyard and its surrounding porticos, and the dome in the centre of the prayer room as well. ${ }^{15}$ The northern area of the mosque has undergone remarkable changes over the last century

${ }^{5}$ Charpentier and Terrasse, L'image de Tlemcen, p. 86.

${ }^{6}$ Marçais and Marçais, Les monuments arabes de Tlemcen, pp. 140-161.

7 Marçais, Album de pierre.

${ }^{8}$ Marçais, Manuel d'art musulman: l'architecture Tunisie, Algérie, Maroc, Espagne, Sicile, pp. 313-320.

9 Marçais, L'architecture musulmane d'Occident: Tunisie, Algérie, Maroc, Espagne et Sicilie, pp. 192-197. In this book he publishes a plan of the mosque with an incomprehensible error as it situates the dome of the centre of the prayer room in the second part of the axial nave instead of in the third.

${ }^{10}$ Golvin, "Quelques réflexions sur la Grande Mosquée de Tlemcen."

${ }^{11}$ Bourouiba, L'art religieux musulman en Algérie, pp. 71-74 and 79-86.

12 Terrasse, "L'esthétique tlemcénienne et son évolution: signes d'échanges méditerranéens."

${ }^{13}$ Charpentier, "Tlemcen et l'évolution des modèles de l'architecture religieuse au Maghreb."

${ }^{14}$ Brosselard, "Les inscriptions arabes de Tlemcen (1)," pp. 89; Marçais, L'architecture musulmane d'Occident, p. 197.

${ }^{15}$ We shall later point out that this dome is a work added on to the original mosque and in its centre shows a large lamp popularly considered a donation by the first 'Abd alWādīi emir. 
and a half as we can gather by comparing the first plans raised in the 19 th century, those published in the 20th and the present condition. We realize that very little can be added to this chronological summary, because while it is not feasible to carry out an analysis of the masonry of the walls without their rendering, it is almost impossible to establish with accuracy which areas were affected by the different phases of construction.

\section{Survey}

Although I was obviously aware of the dome thanks to the bibliography and the numerous images that had been published, as well as the splendid drawings of Marçais, it was not until November of 2011 when I managed to make direct contact with this work. ${ }^{16}$ During a visit to the mosque I was able to take a series of photos, some of which formed stereoscopic pairs, and some straightforward measurements of the width and length of the layout and a height up to the cornice where the dome is set. ${ }^{17}$ During a later visit in $2012^{18}$ I was able to complete the documentation of the exterior of the dome and particularly of the space between the dome and the roof, thanks to the fact that I was given access to the roofs of the mosque, and was able to take photos and measurements of the facade of the prayer room and the minaret.

Thanks to this simple data, and once more back in the School of Arabic Studies, I was able to begin the phase of plotting. This meant calculating first the orientation of the block of photographs of the area of the mihrāb by means of the Orthoware software that enables one to determine the position and direction of each of the images and the coordinates of a series of points that can be observed in at least three photographs, by means of the adjustment of the projective beams corresponding to the measured points that should be intersected in the

16 This was thanks to an invitation to take part in the symposium "711-2011 Treize siècles d'histoire partagée, essai de bilan et perspectives d'avenir" organized by the University of Tlemcen in October, 2011 under the coordination of Prof. Michel Terrasse.

17 A Ricoh GRD compact camera of 10 Mpixeles was used for this, and a pocket laser distance metre, Leica Disto D2.

${ }_{18}$ On the occasion of the symposium "Confluences historiques entre al-Andalus et les Royaumes maghrébins de l'Algérie" held in April that year. 
corresponding positions of the three-dimensional space. To the threedimensional model that was created in this way a scale was given by means of the available measurements, using several to check on reliability and accuracy. The orientation in space was achieved considering that the supporting cornice of the dome defines a horizontal plan, that should not be too far from reality, as no considerable distortions were observed in this part of the building.

The result of this phase of the work was to obtain the $\mathrm{X}, \mathrm{Y}$, and $\mathrm{Z}$ coordinates of 122 points that were to serve as control information for the orientation of the corresponding stereoscopic pairs in the PoivilliersF restitution system. Thus we were able to draw the different elements of the vault and of the components that maintain it and define the space that it covers.

In the phase of stereoscopic plotting I was able to draw the different parts that shape this space: the dome and part of the framework of the axial nave from a couple of photos taken in a zenith direction, the front of the mihra $b$ with another couple of frontal photos, the left hand lateral arch and the access arch from the axial nave with other such photos. Some of the points measured in the bundle adjustment process of the block of photos were useful to complete details such as the cupola of the mihrāb. From all of this a 3D model was created from which it was possible to obtain the plans which we are presenting here, and which include a layout including the projection of the ceiling, a longitudinal section and two cross sections, one following the axe of the building and two perpendicular ones through the axial nave and through the dome, and they were sufficient to define this space metrically and formally.

In the drawings the structural elements are represented together with the frames of the decorative panels, but not in detailed form, because on the one hand the scale of publication of the drawings does not permit an adequate reproduction and on the other hand because the documentation of these areas done by Marçais is of a very high quality, which is undoubtedly difficult to overcome.

Finally we have also achieved the drawing of two complete sections of the building, one along the courtyard with the facade of the prayer room and the other longitudinal along the axis of the mosque, as well as two elevations of the minaret, always using the same procedures. 


\section{Description of the mosque}

If we disregard modern additions, the great Mosque of Tlemcen has a pentagonal ground plan (Fig. 2) due to the fact that its western side has a very sharp angle that Marçais supposed was due to the existence of the original residence of the Emirs or Qașr al-Qadima on that side of the mosque. That lasted until the 'Abd al-Wādid period when it is transferred to the Mashwar, which has survived up until the present day. The prayer room is rectangular, $51.25 \mathrm{~m}$ wide by 26.80 deep $(49.00$ x 25.00 inner measurements), with almost identical proportions to those of the first Great Mosque of Cordoba of 'Abd al-Raḥmān I (73.60 x 38.00 ), although it was smaller in size.

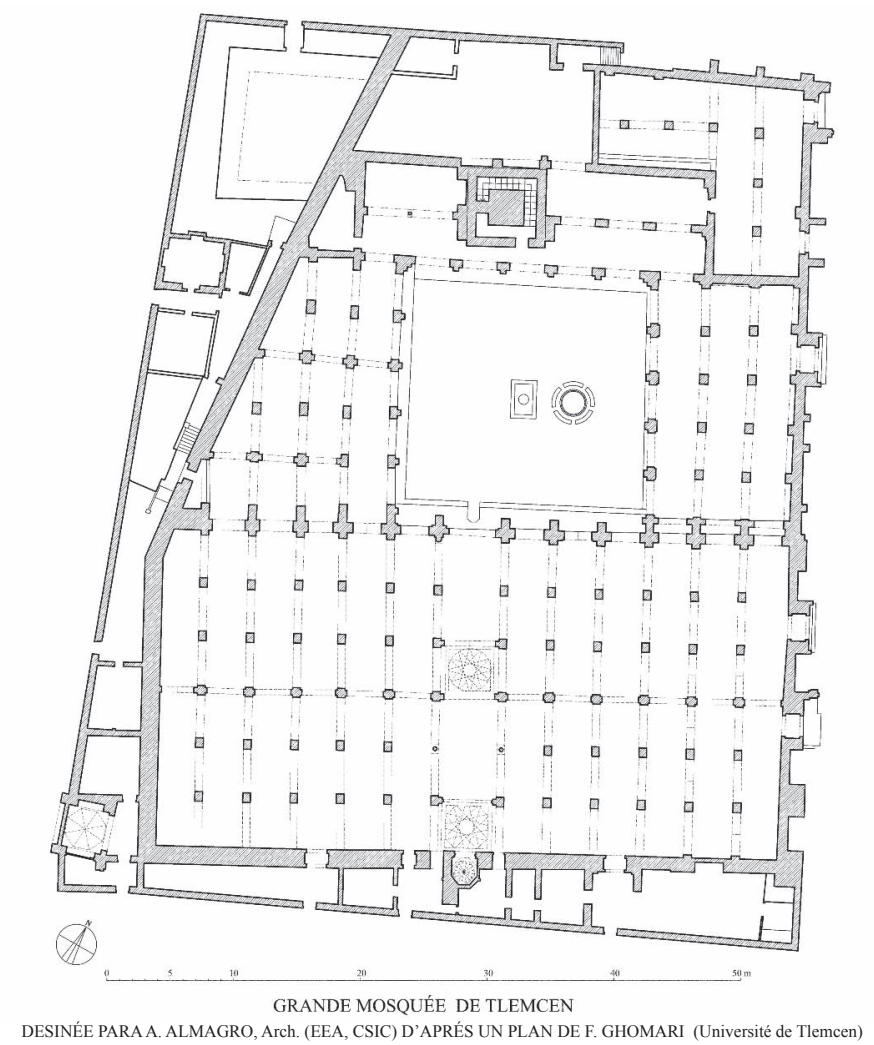

Figure 2. Present ground plan of the Great Mosque of Tlemcen (Drawn by the autor based on a sketch provided by Prof. Fouad Ghomari of the University of Tlemcen). 
The mosque of Tlemcen responds to the western model of sanctuary consisting of naves running perpendicular to the qibla wall, in the version which becomes more generalized as from the 12th century with the Almoravids and the Almohads, when the arcades are supported on brick pillars and not on columns, although in this case we can recall the model from Cordoba with support columns, as in the central nave two arches from each side are supported on columns with their corresponding capital and cymatium.

The prayer room has thirteen naves delimited by arcades of six bays each, mostly of extended rounded arches reaching up to a horseshoe (Fig. 3 and 4).

There are another two transverse arcades, parallel to the qibla wall; one divides the hall in two equal parts and another forms the façade of

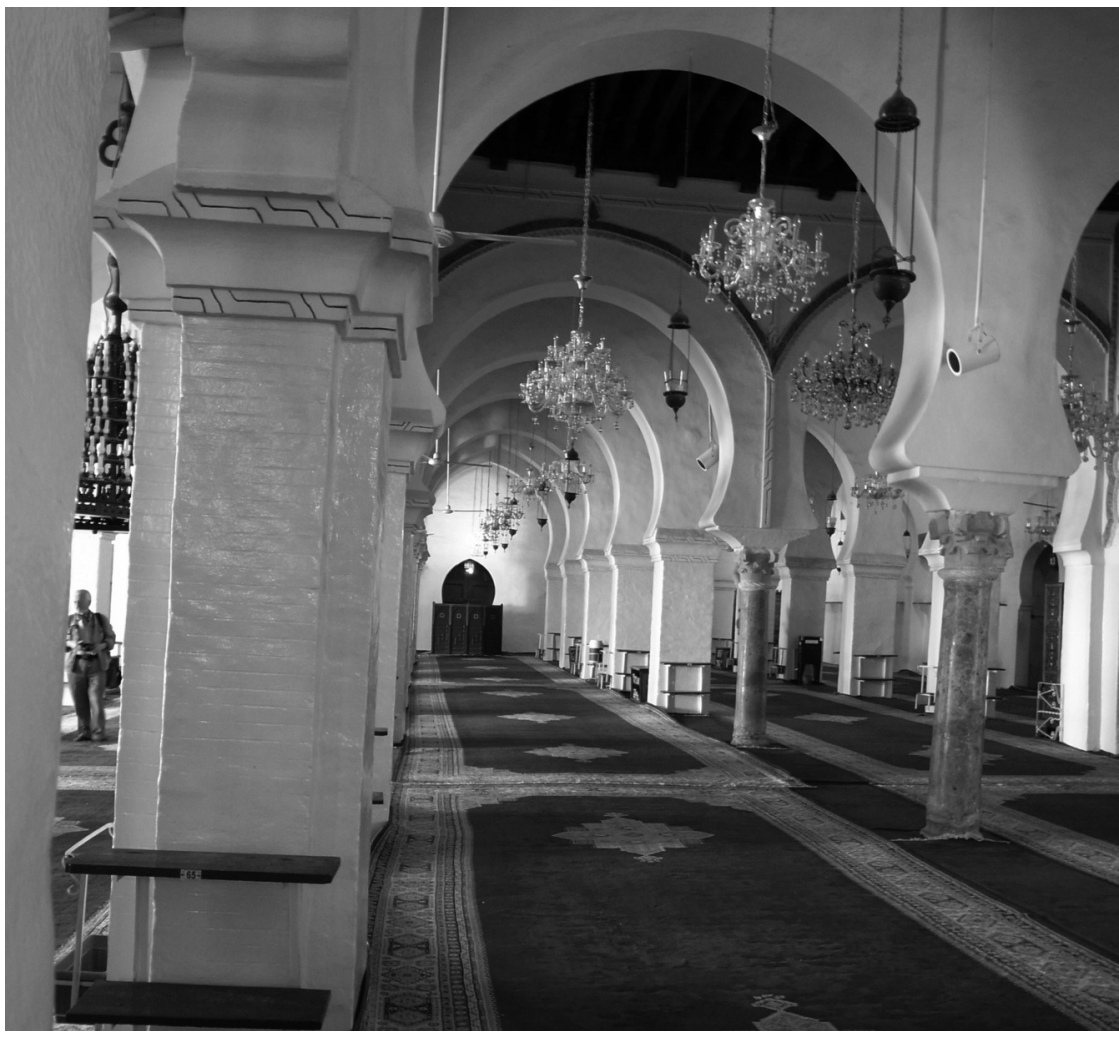

Figure 3. View of the prayer room of the Great Mosque of Tlemcen (A. Almagro). 


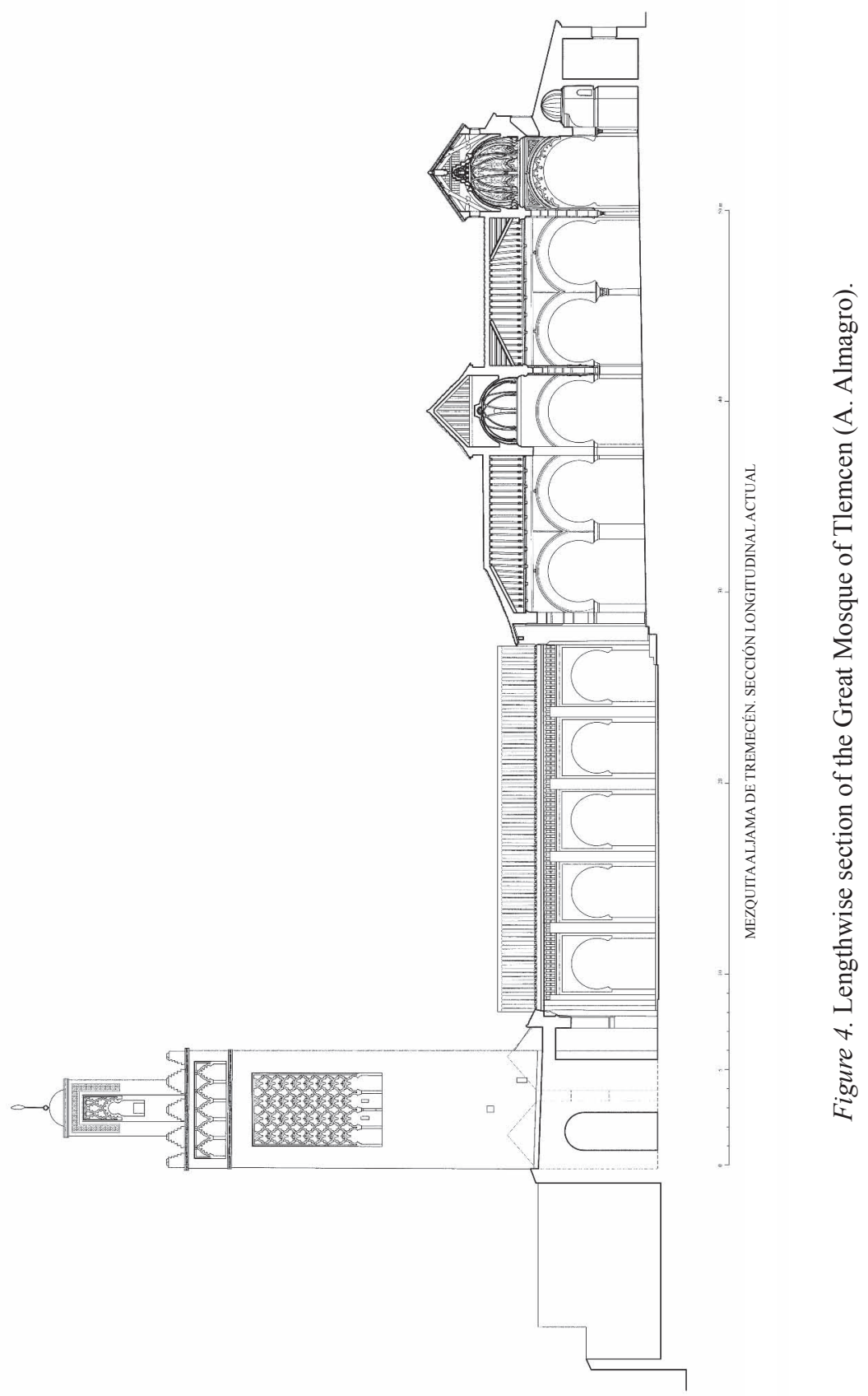


the hall towards the courtyard or șahn (Figs. 5 and 6). The central one is formed by lobed arches, of 11 lobes corresponding to the axial nave, of 9 lobes the two adjacent ones and of 7 the rest, except for the last on the western side and the two last on the eastern side which are pointed horseshoe arches. This lack of symmetry on the eastern side is also seen in the fact that the arches of the two outer arcades are pointed and not rounded arches, which may be due to refurbishment of this part of the oratory, maybe due to being in ruins in Almohad or 'Abd al-Wādìd times. The fact that the outer wall on that side is less thick and has buttresses would point in the same direction. The idea that the central arcade might have been the façade of the courtyard of a first prayer room of three lengths later extended with another three ${ }^{19}$ is not acceptable, because the pillars supporting it would have counteracted with difficulty the thrust of the arcades separating the naves. The prayer room would also have been disproportionately wide and not deep enough.

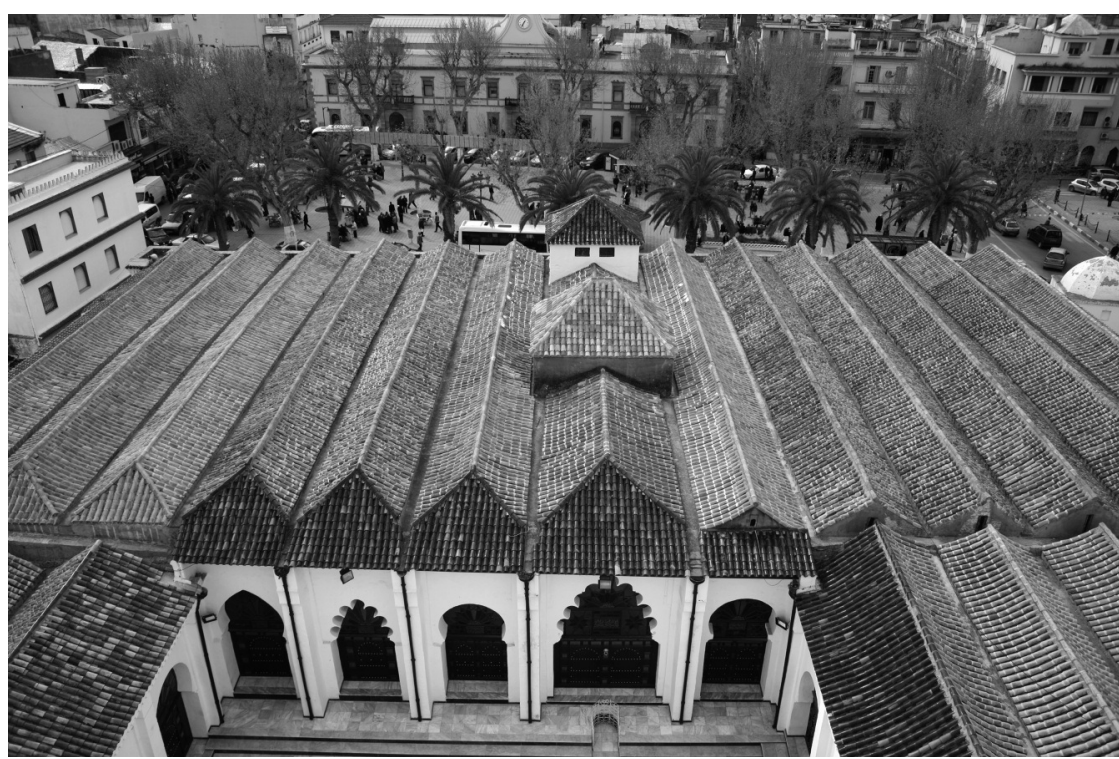

Figure 5. View of the roofs of the Great Mosque of Tlemcen (A. Almagro).

${ }^{19}$ Hoag, Arquitectura Islámica, p. 98, based on Marçais, L'architecture musulmane d'Occident, p. 197. 

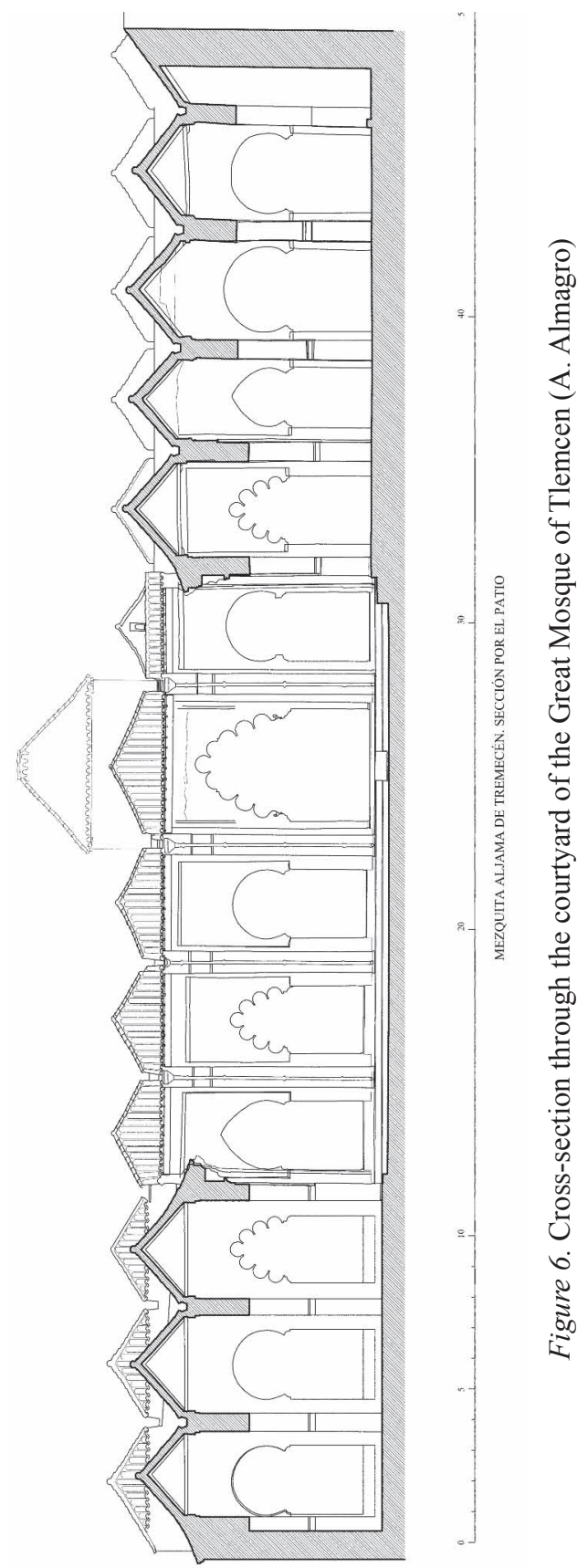

Al-Qantara XXXVI 1, 2015, pp. 199-257 ISSN 0211-3589 doi: 10.3989/alqantara.2015.007 
The arcade forming the façade towards the courtyard has different shaped arches (Fig. 6 and 7). The arch corresponding to the central nave has 9 lobes, with "serpentine" forms in its springs, characteristic of Almoravid and Almohad art, but with the peculiarity that the appendices that form between the second and third lobes starting from the keystone on both sides are trimmed by some mixtilinear shapes that give it a very original profile. Adjoining both sides there are semicircular horseshoe arches. The following ones have 7 lobes and a base in simple cavettos, and the following are very pointed horseshoe arches. From this point the ends of the façade lose their symmetry, maybe due to the late alterations.

The room has a courtyard or sahn added to it, but in its present form this does not seem to correspond to the original design, since it has been moved towards the east with regard to the axis of the prayer room. The ground plan is practically square, $19.80 \times 20.40 \mathrm{~m}$ and is surrounded by porticos that on the eastern and western sides are an extension of some of the naves of the oratory. On the northern side there is a portico of two naves interrupted by the minaret that seems to be disconnected from the general composition, since it does not follow the axis either of the prayer room or that of the present day courtyard and its arcades. The arches on the three porticos of the courtyard are semi-circular horseshoe shaped, with the exception of the central one on the northern side which is lobed, with nine lobes, its base being a simple cavetto (Fig. 8).

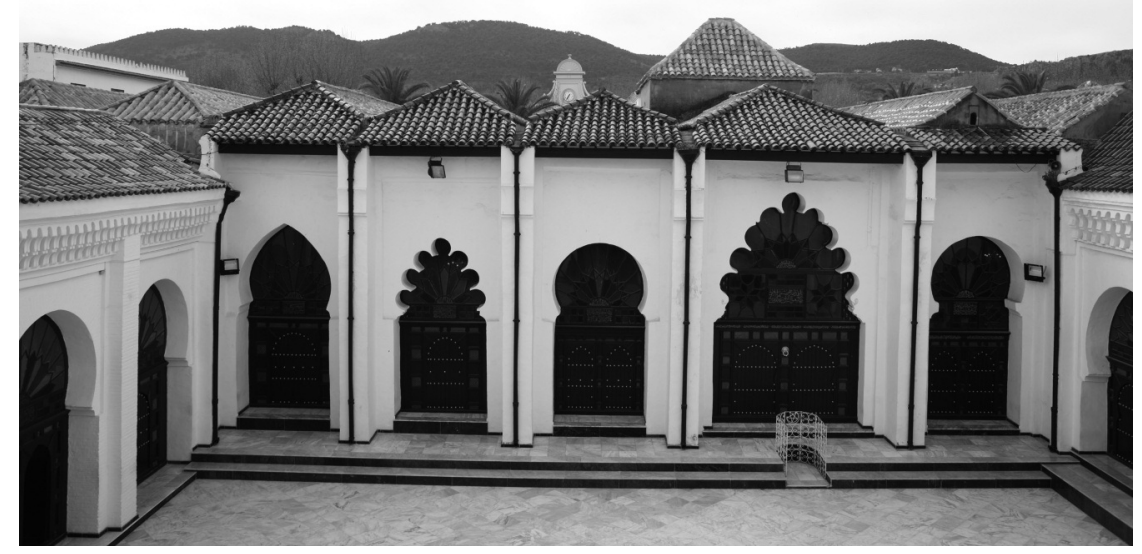

Figure 7. Façade on to the courtyard of the prayer room of the Great Mosque of Tlemcen (A. Almagro). 


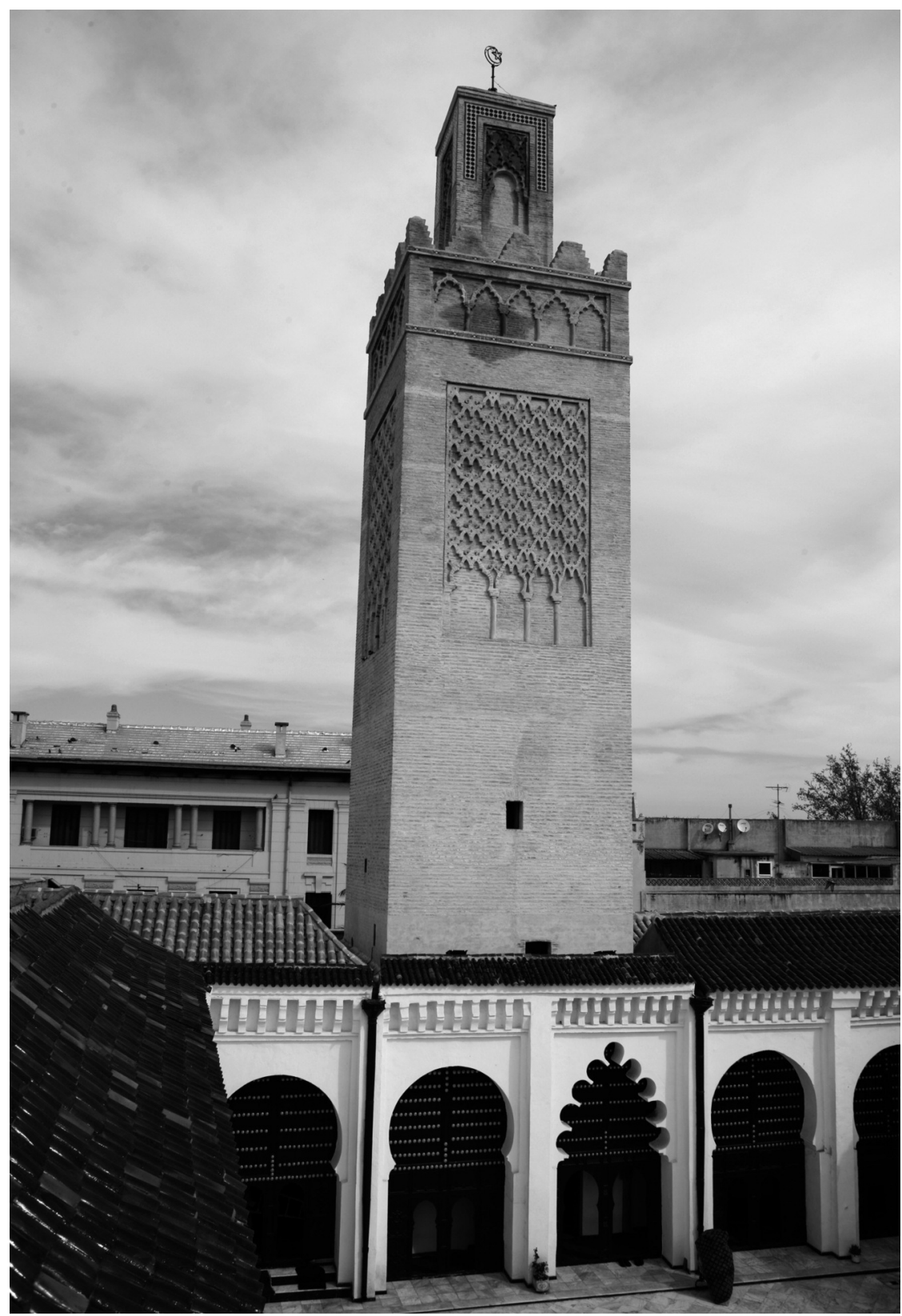

Figure 8. View of the minaret and the courtyard of the Great Mosque of Tlemcen (A. Almagro). 
The central nave of the oratory is wider than the rest $(4.60 \mathrm{~m}$ as opposed to $3.15 \mathrm{~m}$ ). Initially it must have been segmented by two arches: that of the façade as already described, and that of the transversal portico in the centre of the room. Subsequently the one which defines the maqșüra (Figs. 6, 9 and 10) would be added and later another arch to delimit the space next to the transversal archway which was covered with a dome (Figs. 2 and 4). In this last case we are dealing with a later work, which is endorsed by the fact that the new arch is neither lobed nor is it a semicircular horseshoe arch. It is a pointed horseshoe one, which would relate it with the supposedly remade ones on the eastern side of the room. Besides, in order to fit a square space inside that stretch of the nave that is rectangular because its width is greater than the distance between the axes of the pillars of the porticos, they added to them two low arches that in their support interfere in the decoration accompanying the central arch of the transversal arcade of the room. Although this solution is similar to that which was adopted for the other dome situated next to the mihrāb, in that case the decoration was arranged taking into account the presence of the adjoining arches. This indicates that in the case of the central dome the adjoining arches were carried out when the decoration already existed and therefore it is at a later date. ${ }^{20}$ In order to pass from the square plan achieved in this way to the circular one, four triangular plans were set with one of their sides curved, in the centre of which there are designs of eight pointed stars.

This first dome (Fig. 11) is hemispherical and strengthened with 12 arches in relief and interlaced to form a 12-pointed star and a central twelve-sided polygon. This has a flat end in which we can see another star of a very thin relief which is also 12-pointed and whose central area has a ribbed cupola. Although these solutions are inspired in the other dome, they are all much simpler and more ungainly, which are indicative of a different chronology for both of them.

The central arch of the transversal arcade has 11 lobes that rise from the imposts by means of a characteristic "serpentine" motif, according to the terminology of Marçais (Fig. 9). The extrados of the arch is marked by another one, formed on each side by two series of palm leaves separated by short rectilinear stretches. They are accompanied

${ }^{20}$ Marçais, L'architecture musulmane d'Occident, p. 197. 


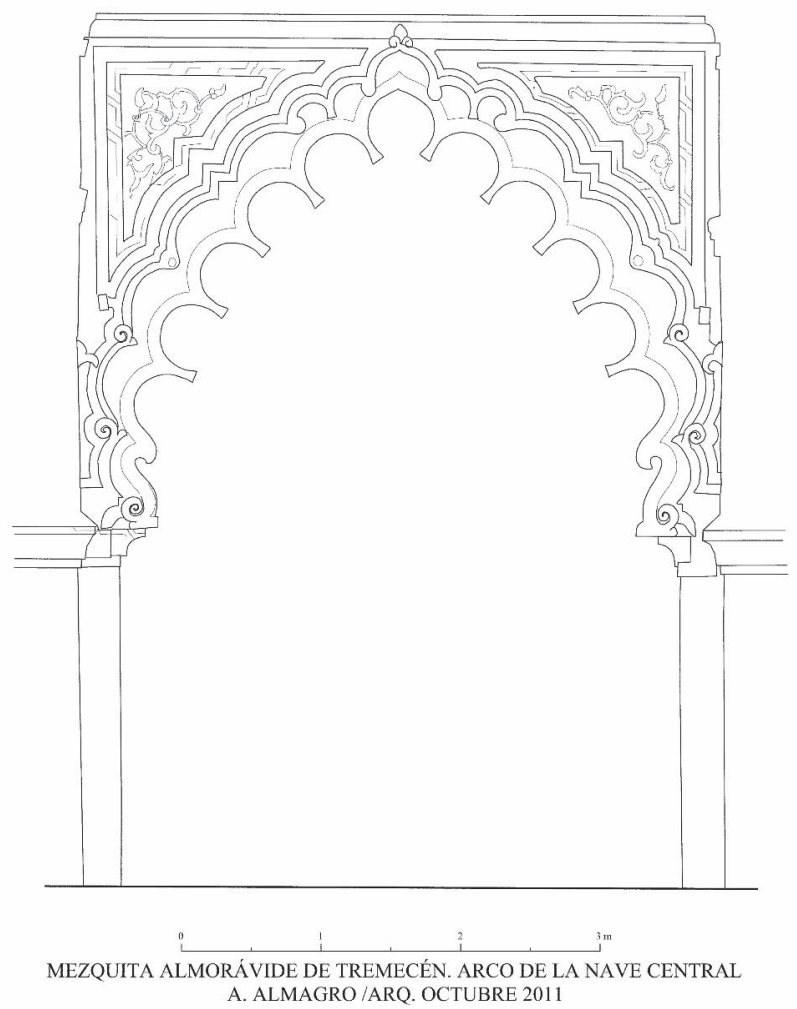

Figure 9. Arch of the transverse arcade of the prayer room in the central nave (A. Almagro).

by mouldings that contain spandrels decorated with arabesques. The rear face of the arch has a similar decoration. After crossing the first dome, the second sector of the central nave has the special feature of having two supports formed by columns instead of rectangular pillars, which allows the space to be more diaphanous than the rest of the mosque. This is emphasized by the presence of arches that have a greater number of lobes in the transversal arcade. ${ }^{21}$

The arch indicating the end of the nave adjoining the second dome is supported by columns that are partially embedded in the pillars with

21 Terrasse, “L'esthétique tlemcénienne," p. 244. 
a $\mathrm{T}$ ground plan, thus demonstrating a greater hierarchy of this space and maintaining unity with the previous supports formed only by columns (Fig. 10). As in the anterior arch in the centre of the prayer room, another mixtilinear arch also including sections of palm leaves, marks its extrados and makes up the spandrels. On the ones on the front

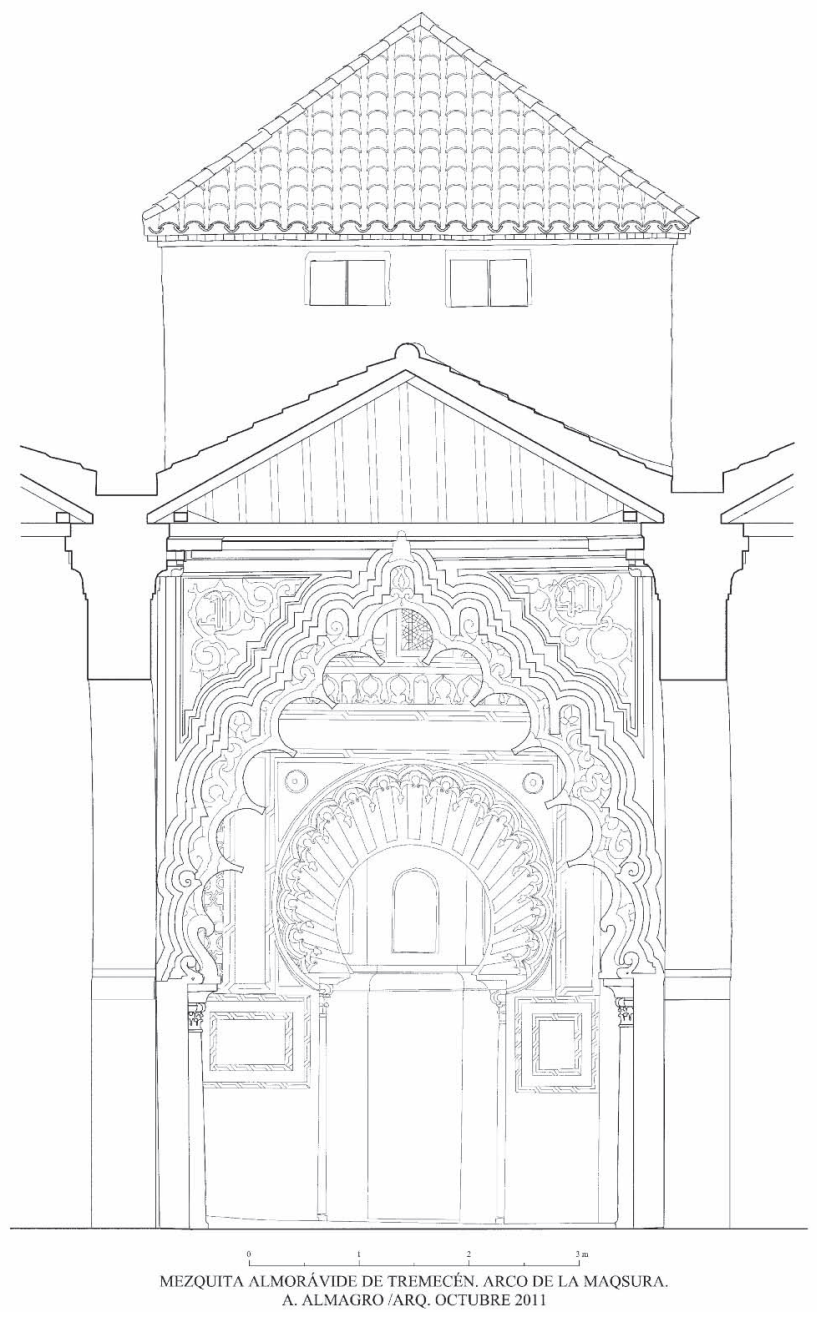

Figure 10. Cross-section of the nave with the access arch to the maqșüra (A. Almagro). 


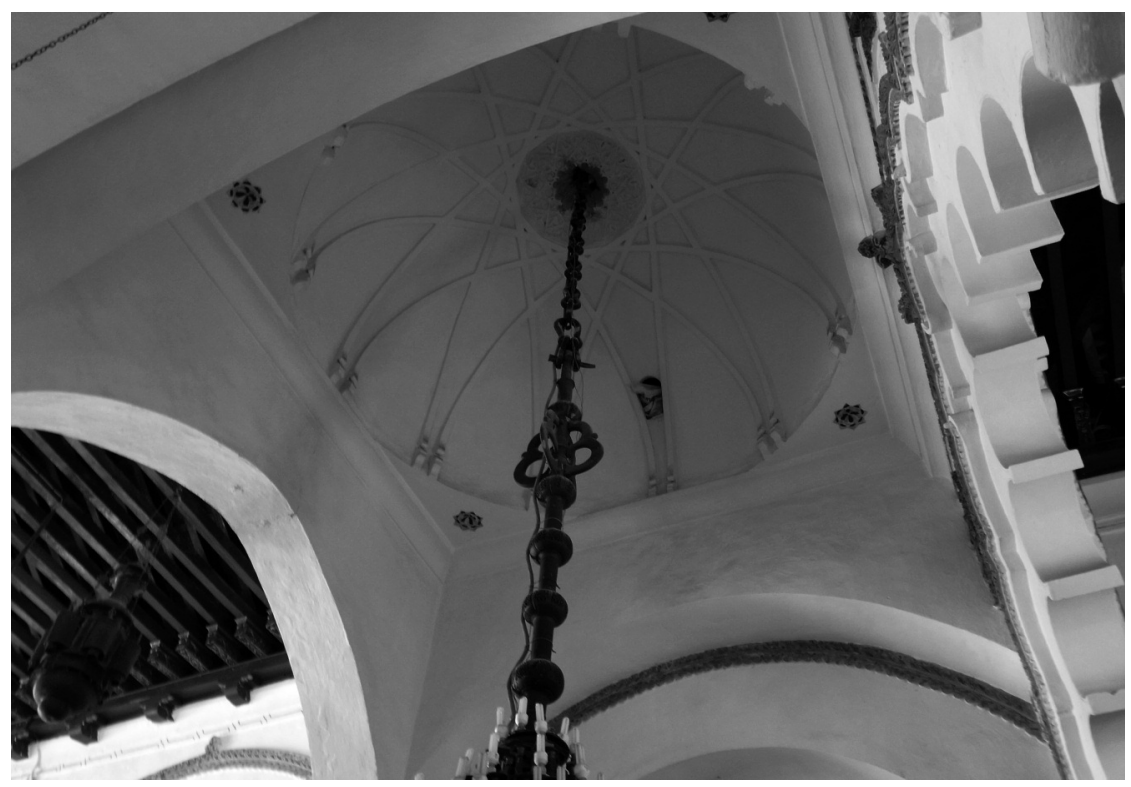

Figure 11. Interior view of the dome situated in the centre of the prayer room (A. Almagro).

of this arch we can appreciate epigraphic decoration inside scrolls that are extended into palm leaves with arabesque background in deep relief. Between the mouldings and the lobed profile there is a simple incised decoration of smooth palm leaves of the type that appear extensively in Almohad art. On the rear of the arch there is similar decoration although the spandrels are smaller in size to adapt to the support of the adjoining arches previously mentioned.

In this mosque the ' $\mathrm{T}$ ' shaped ground plan characteristic of Almohad oratories and that is gradually suggested in the extension of alHakam II in the mosque of Cordoba, has not yet been adopted. To the contrary, the naves and their arcades reach directly up to the wall of the qibla without the existence of a parallel arcade that links the final pillars, in spite of the fact that there is only one arch with this direction to define the area of the maqșura.

In the light of the general ground plan of this mosque there may be good reason to consider the influence of the Great Mosque of Cordoba, although with obvious simplifications due to its smaller size. Two facts 
should be highlighted here: in the first place the compositional predominance of the axial nave, not only due to its greater width and the presence of the mihrāb at the southern end, but also for having partitioned it with two sectors covered with domes that interrupt the rhythm of the wooden roofs that extend throughout the rest of the prayer room. On the other hand we should also emphasize the composition of the transversal arcade, formed by lobed arches, that divides this space into two equally-sized areas. This characteristic already existed in the mosque of Qayrawān in the 9th century and could be justified for bracing laterally the arcades of the naves. In this case it has a special feature of having one of the domes previously mentioned associated, that is a solution recalling that which was created in Cordoba with the extension of al-Hakam II when arranging the dome of the Villaviciosa chapel at the beginning of the extension of the central nave. In this way it was located in the centre of the oratory, linked to the arcade placed to substitute the qibla wall of the of 'Abd al-Rahmān II. In spite of it being unnecessary in Tlemcen for this dome to be a skylight to illuminate the centre of the oratory, its position there and not at the beginning of the nave, as in the case of Qayrawān, leads us to believe in the probable influence of the great oratory of Cordoba in this respect. However, we are dealing with a transformation of the original project, as we have already mentioned.

\section{The space in front of the mihrāab}

The space that stretches between the last transversal arch and the wall of the qibla is also rectangular in form, since the width of the central nave of the mosque $(4.60 \mathrm{~m})$ is greater than the span of the side arches $(3.80 \mathrm{~m})$ (Fig. 12). The latter ones are horseshoe arches of circular profile and they arise from simple imposts that are flat on the front, because they only project in the direction of the span. In order that the high part of this space may adopt a square shape, on the inner surface of the side arches other arches were attached with a concentric profile and slightly raised and as they are resting on the wall of the qibla and on the transversal arch of the central nave they have a diminished shape. On the front of the lowest arch there is a decoration of five small tri-lobed arches rising from "flying" imposts, since they are not supported on columns nor on any other type of support and they 


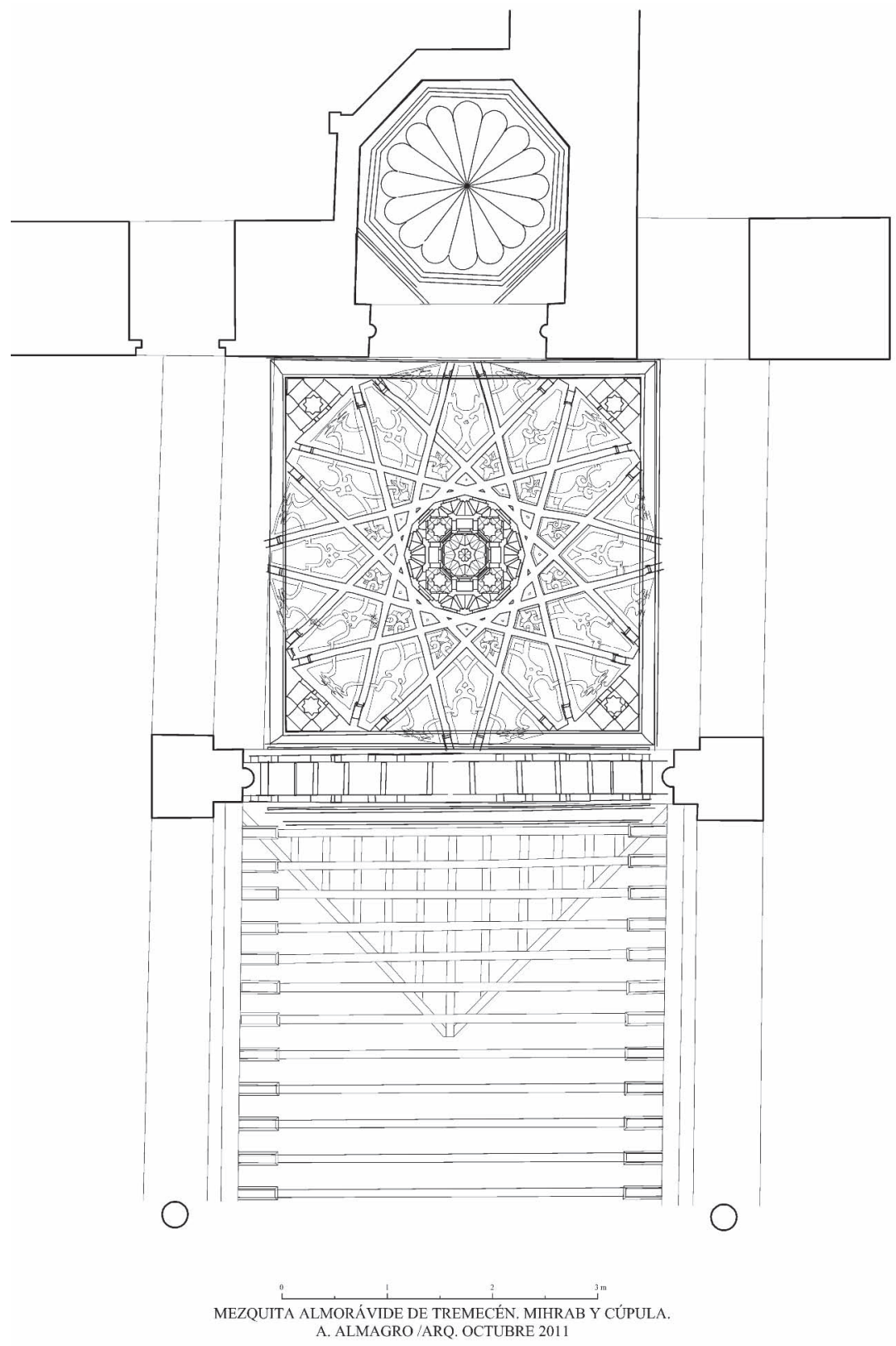

Figure 12. Plan of the area of the maqșurra with projection of ceilings (A. Almagro). 
remain as mere linking elements which give continuity to the small arches (fig. 13). The last "supports" do not have imposts but rather some finishes of palm leaves that curve in on themselves and link up with some final semi-arches that complete the composition. The im-

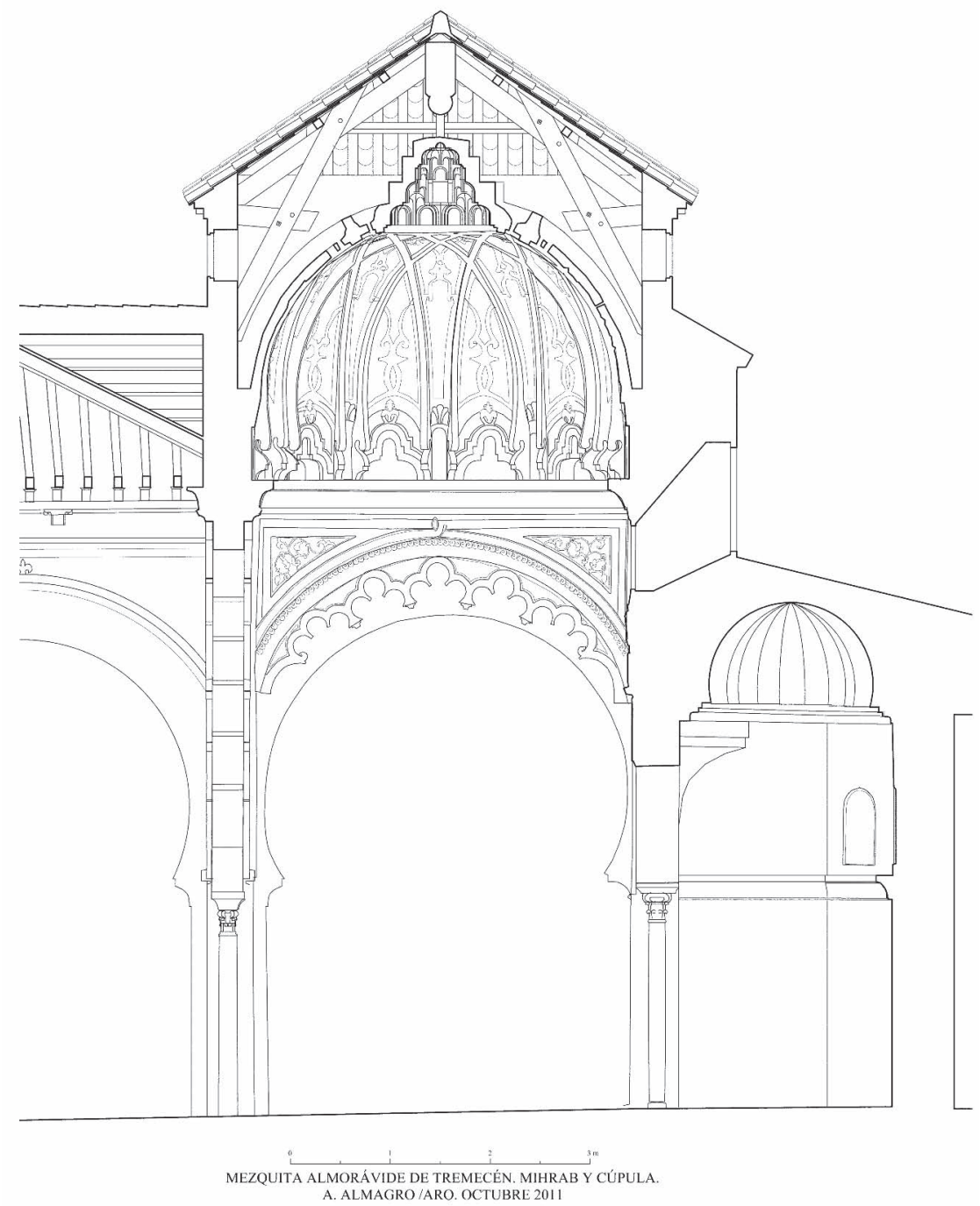

Figure 13. Lengthwise section of the area of the maqșüra and of the mihrāab (A. Almagro). 
posts without support constitute a widely used motif in the decoration of interlaced arches in the Aljafería of Zaragoza, where the smooth palm leaves we see here do not appear yet. The spandrels of the diminished arches that are more to the interior are filled with the decoration of scrolls of palm leaves on a background of arabesques.

The composition of the doorway framing the mihrāb is the most richly decorated area (Fig. 14). The niche is of the Al-Andalus type, is very deep and has the shape of a space satellite to which we can attribute a certain spatial autonomy. ${ }^{22}$ The inner ground plan is octagonal with two parallel side walls which are perpendicular to the entry arch. At a height of $2.08 \mathrm{~m}$ from the ground there is a cornice in cavetto with a Qur'ānic inscription in Kufic script. Above this, in the three faces that form the far end, there are three small semicircular arches which are closed with a variegated decoration of arabesques that are deeply carved and perforate the panels and which originally allowed light to pass through the interstices of the plant network. ${ }^{23}$ Beginning from a certain height in the adjoining corners to the access arch two squinches are formed that allow the niche at a high level to adopt an octagonal form. A small flat ceiling serves as a base for a ribbed cupola of 16 segments whose starting lobules are scalloped by a simple band decoration. This space communicates with the prayer room through a horseshoe arch resting on imposts supported by columns embedded in the jambs, which is a solution clearly rooted in the tradition from Cordoba mosque. This arch and its environment make use of all the typical syntax of Caliphate art (Fig. 15). The front parts of the jambs have panels that are decorated with fine arabesques bordered by narrow epigraphic bands with texts from the Koran. The arch is framed by a first alfiz (surround of the arch) with large sized Kufic lettering with a background of arabesques and scalloped with a double interlaced band which forms in the angles two eight-pointed stars also filled with arabesques.

22 A close parallel to this is the mihrāb of the prayer room recently discovered in the qasbah of Murcia which has conserved a rich polychromy that maybe existed in the decoration of Tlemcen (Navarro Palazón and Jiménez Castillo, "La arquitectura de Ibn Mardanish: Revisión y nuevas aportaciones," pp. 343-344, figs. 15-20).

${ }^{23}$ The decoration of these windows was drawn by Marçais in his album (Album de pierre, $\mathrm{Pl}$. IX, X). 


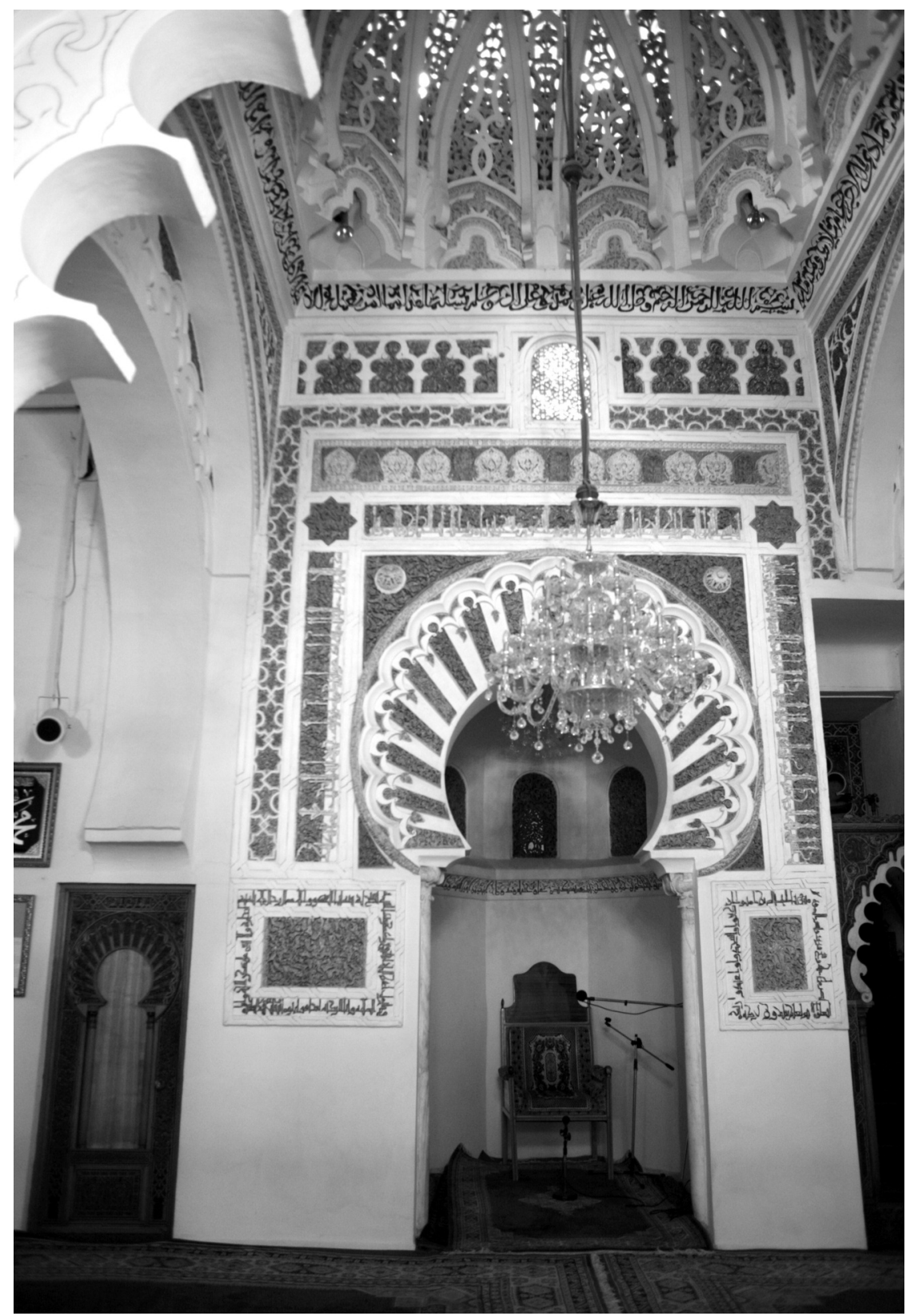

Figure 14. View of the façade of the mihrāb with its luxurious decoration (A. Almagro). 


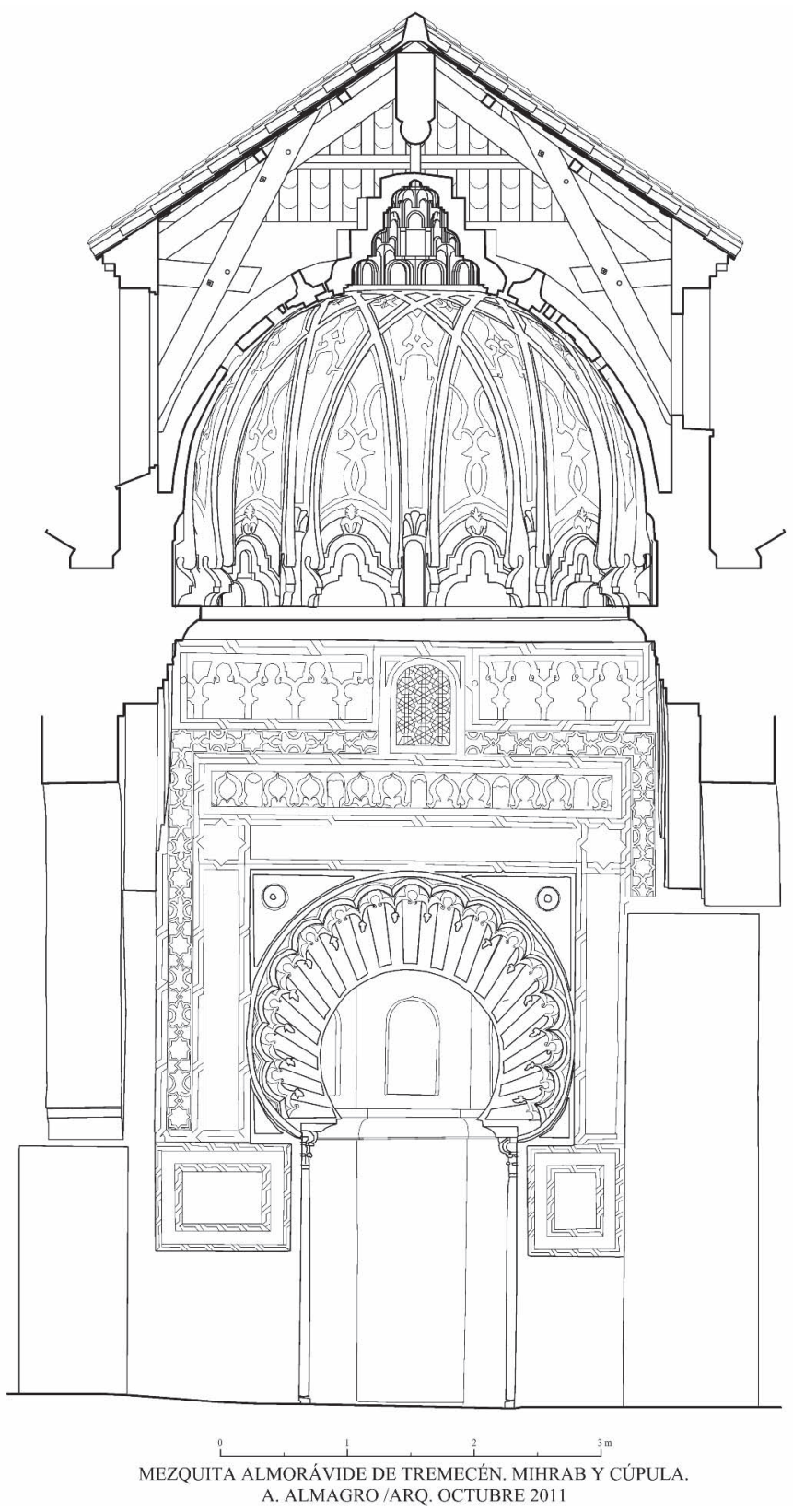

Figure 15. Cross-section of the maqșüra with the façade of the mihrāa b (A. Almagro). 
The voussoirs of the arch follow the characteristic variation of the Cordoba tradition with some plain pieces and others covered with arabesques. The line of the upper surface is formed by a lobed arch within which other trefoils are developed, formed by palm leaves which rise from small fruits in the shape of pimentos. The spandrels have bulb-shaped circular adornments that stand out over the floral decoration that fills the triangular spaces.

Over the horizontal part of the first alfiz there is a decorative band with alternating large acanthus leaves with coupled compositions of palm leaves. The first alfiz and its decorative bracket are surrounded by a second alfiz with plant decoration framed by a border which consists of stars of eight points and other shapes with curvilinear edges. This alfiz is cut through the centre by a window that also encroaches on the figure directly above and which consists of a strip of small trefoil blind arches supported by small columns and filled with arabesques. This frieze completes the decorative syntax established in Caliphate art for the composition of a façade, although in this case the small arches are scant in size and therefore have reduced visibility, so they are only a mimic that seems to want to fulfil composition guidelines that were to be overcome.

Finally, a cavetto-shaped cornice crowns the four sides of this space and serves as a formal and structural support to the dome covering it (Fig. 16). This cornice has an inscription around it in which the writing in cursive style or naskhi is accompanied by a secondary composition of floral scrolls and palm leaves. The text reads: ${ }^{24}$

In the name of God, the compassionate and merciful, God bless and save Muhammad and his family. This was ordered to be done by the eminent /Emir [..... may God support him in his power, intensify his triumph and perpetuate his/State. It finished under the direction of the very illustrious and very generous attorney qadí Abū l-Ḥassan `Alī b. 'Abd al-Raḥmān b. 'Alī. May God perpetuate his glory. It finished in the month of Jumādā II of the year 530. (April, 1136).

24 This inscription was published by Charles Brosselard ("Les inscriptions arabes de Tlemcen," pp. 86-87). 


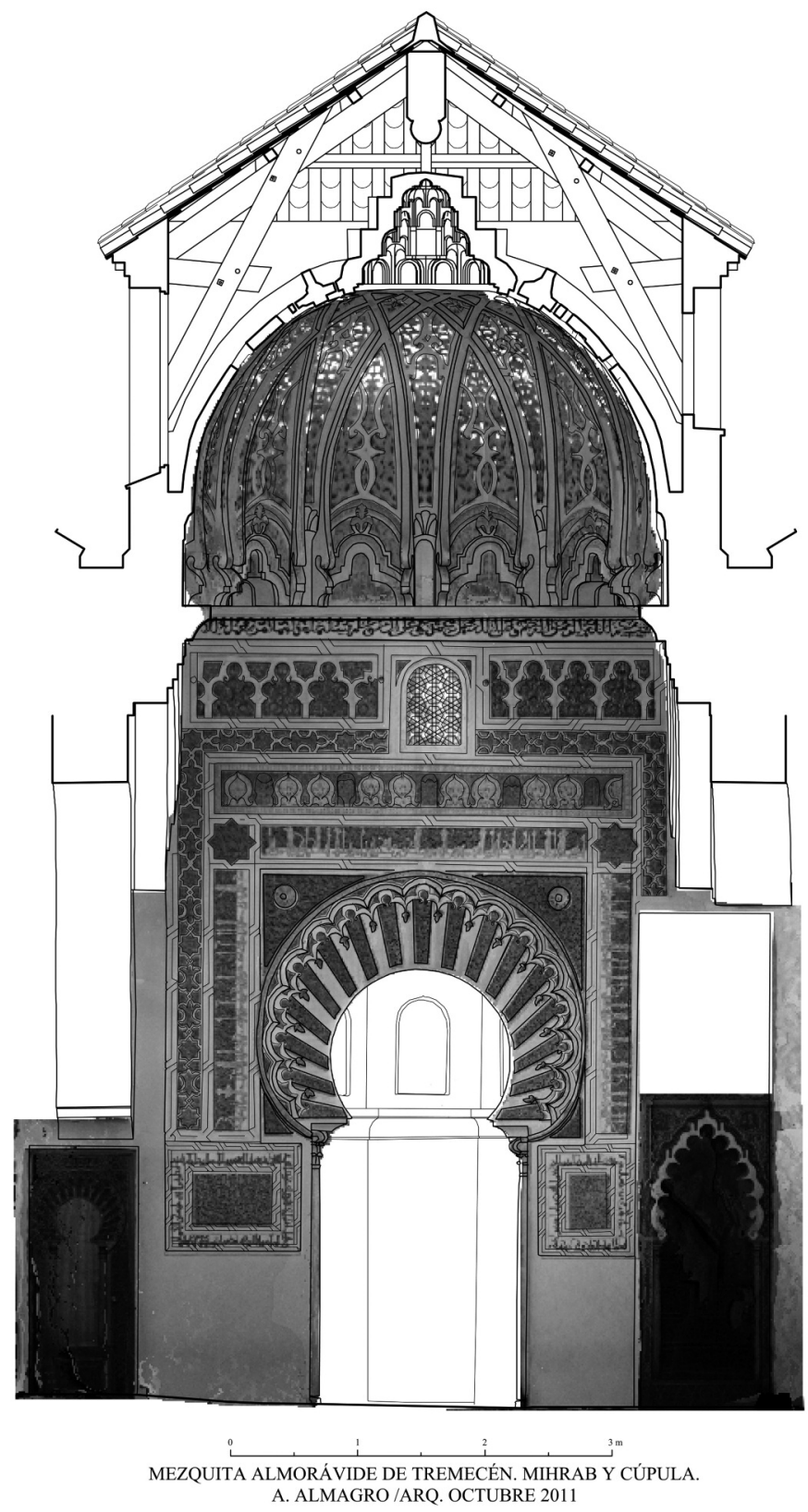

Figure 16. Cross-section of the maqșūra with orthophoto of the façade of the mihrāb (A. Almagro). 
The name which should be included in the area in brackets was eliminated, may because of a damnatio memoriae which could be easily attributed to the Almohads. The date, however, leaves no doubt that it refers to 'Alī b. Yūsuf, the Almoravid Emir whose government lasted from 1106 to 1143.

On top of this cornice there is a covering system based on thin interlacing arches and on which perforated web spandrels are supported ${ }^{25}$ and we shall describe them further on.

At this point we must focus our attention on a series of anomalies presented by the composition of this doorway of the mihrāab. The first thing that attracts our attention is the existence of two doors, one on each side of the niche, although without maintaining any symmetry. Both are open under the support of the side arches that form this space. The left hand door is scarcely $1.95 \mathrm{~m}$ in height and respects the impost at the foot of the arch. However, the right hand door which is $3.90 \mathrm{~m}$ meant cutting off the lower part of the arch that forms a torus in order to reach the wall. This aperture is used to hide the minbar and is nearer to the mihra $\bar{a} b$ than the aperture of the other side. These openings are no doubt modifications of the original project that are very questionable from a structural point of view, since it means that the arches rest on apertures made in the walls, which is hardly a very feasible solution.

The presence of the opening on the right hand side, which is the placement of the minbar, is the reason for the majority of the alterations in the composition and decoration of the doorway, in which the mihrā $b$ opens up as it leads into the space of the maqșura.$^{26}$ For this reason the decorative band of the second alfiz is interrupted by the lintel of the opening. Alterations also take place in the panel of arabesques with an epigraphic border situated on the front of the right hand jamb of the arch which is smaller in size than the one on the opposite side. Together with this we can observe other asymmetrical details, although they do not seem to be related. So the lattice-work window over the mihra $\bar{b}$ is

25 Torres Balbás, "Bóvedas caladas hispanomusulmanas."

26 A similar solution also carried out a posteriori was adopted in the Great Mosque of Cordoba although there it was done in a cleaner way because the gap did not open under the support of the arch but beside it, taking advantage of the fact that the maqsüra occupied not only the section next to the mihrāab but also the two adjacent ones (Fernández Puertas, Mezquita de Córdoba. Su estudio arqueológico en el siglo XX, pp. 224-225). 
situated slightly towards the right with regard to the axis of the composition (about $7 \mathrm{~cm}$ ). The frieze underneath this window, and set between the first and second alfiz can also be seen as asymmetrical, because it seems to be centred with the axis of the window with the result that while the left hand is crowned with a motif of two symmetrical palms, there is only one on the right hand side. Strangely enough, the decorated border that constitutes the external alfiz and which is cut off by the window has an apparently asymmetrical number of stars and mixtilinear shapes, although the latter turn out to be longer on the left than on the right. These differences are maintained in the vertical sections, which no doubt would have meant that the one on the right hand side would have crowned in an anomalous way if it had not been interrupted by the presence of the opening of the minbar. Finally, in the frieze of small blind arches that crowns the composition of the doorway and that is also interrupted by the window, the left hand ones are somewhat wider than those of the right, including the half arches adjoining the frame of the window.

It is definitely worth considering what these anomalies are due to, and the reply undoubtedly arises that they are caused by the presence of the small window above the mihrāb and the opening of the minbar. The following question that is raised is whether these anomalies are the fruit of alterations in the decoration carried out due to the aperture of these openings or whether the openings already existed and what was done was an adaptation of the decorative elements to conceal the pre-existing inadequacies. From what has already been explained and what we shall say below I think that we may be able to deduce that this second hypothesis is the most likely one.

The decoration has been fulfilled with an extremely high quality, and presents no signs of having been retouched. The greatest doubt arises from whether the border of the external alfiz and the panel of arabesques on the right could have been cut on making the opening of the minbar. We have already pointed out that the border on this side shows differences with regard to the symmetric one, which would have given rise to a strange top at the height of the imposts of the arch of the $m i h r \bar{a} b$ if it had not been interrupted much earlier.

Regarding the panels of arabesques, we should mention that the left hand one measures $62 \mathrm{~cm}$ wide and 41 high. It consists of a composition with a central vertical axis which does not make any symmetry due to 
the freedom of the craftsman in carving the details of the arabesques. It has two different borders based on leaves on the vertical edges, and lacks the horizontal edges. There are two different borders with leaves on the vertical edges, but the horizontal borders are missing. The right hand panel measures $32 \mathrm{~cm}$ in width by 45 in height and only has a border of leaves on the left. Apparently it seems to be formed by half of a panel similar to that of the left hand side, although we cannot be sure whether it was cut away or carved on purpose with only half the composition, but it attracts our attention that it is higher than the other. Both panels are bordered by an epigraphic band with Qur'ānic texts in Kufic lettering, and neither side seems to have undergone mutilation.

We would like to stress once more the opinion already mentioned that all this decoration was carried out in this way in order to adapt to pre-existing openings. This leads us to elaborate on the hypothesis that was pro-

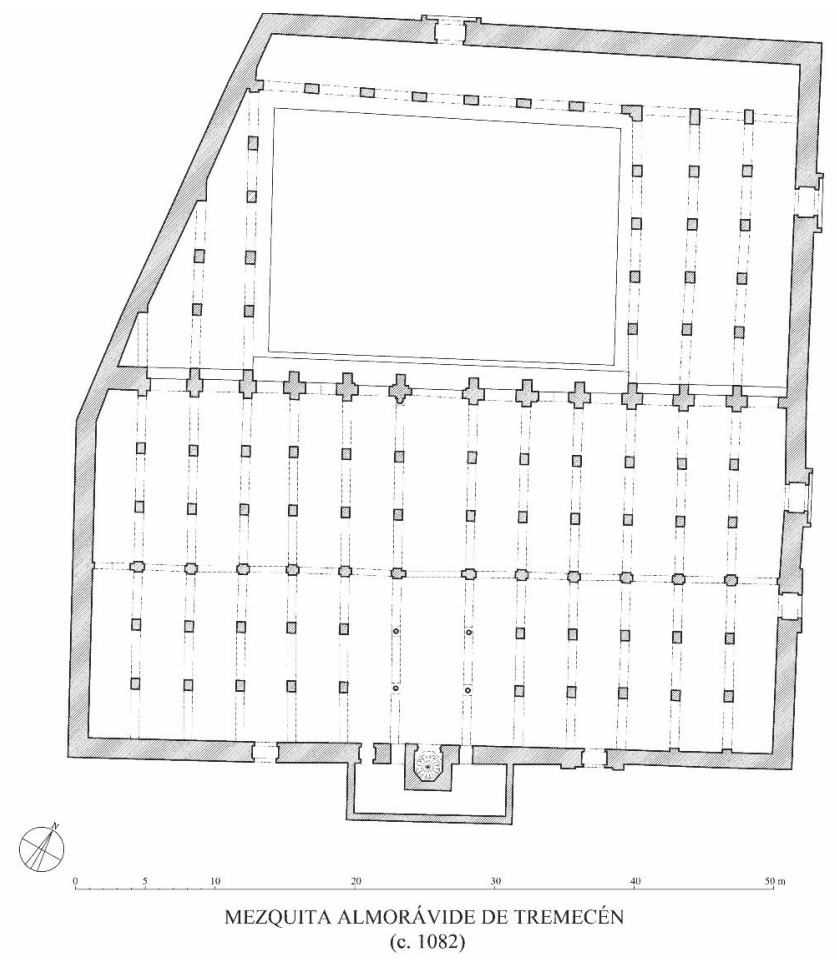

Figure 17. Hypothetic plan of the original Great Mosque of Tlemcen at the end of the 11 th century prior to the construction of the dome of the maqșura (A. Almagro). 


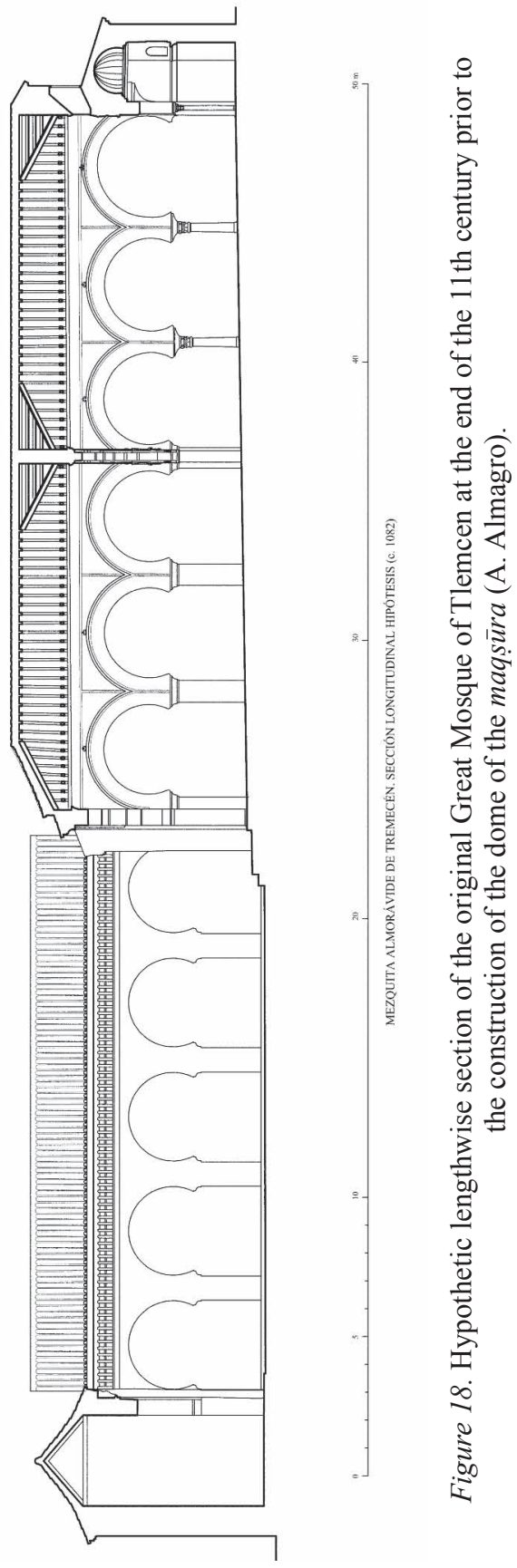

Al-Qanțara XXXVI 1, 2015, pp. 199-257 ISSN 0211-3589 doi: 10.3989/alqantara.2015.007 
posed by Marçais, ${ }^{27}$ that the mosque of Tagrart was constructed by Yūsuf b. Tashufin at the same time as the city was founded about 1082, and that the date which appears on the cornice corresponding to the government of his son 'Alī $b$. Yūsuf refers to the undertaking of the decoration. The first mosque must have lacked a dome over the maqșüra nor did it have decoration (Figs. 17 and 18). The opening of the minbar, similar to what happened in the mosque of Cordoba, must have been carried out once the first prayer room was built, but prior to the decoration being added. The small window over the mihrāb also existed in the original construction and its location was respected and the decorative panels were adapted.

\section{The dome}

The structure covering the space of the maqșīra is undoubtedly one of the most beautiful and interesting works of Western Islamic art (Fig. 19). This is a raised hemispheric dome which is reinforced by twelve ribs, although in structural terms we should speak of a set of twelve interlaced arches that support a series of spherical panels, whose special feature is a rich decoration and they are perforated to allow the light to enter from the area of its extrados. It must be pointed out that this structure is only self-supporting, as no other element rests on it. Above it there is just a wooden framework leaning on the peripheral walls, which support a roof (Fig. 15). The present structure is visibly a modern one, no doubt from the colonial period to judge by the structural solutions that are completely alien to Hispano-Maghrebi traditions. There are also metallic joining elements that proceed from industrial manufacture. This structure rests on a coffer with a square base whose walls hang over the wall of the qibla, the lobed arch of the central nave and the two low arches adjoining the last of the arcades of the central nave, so as not to interrupt the drainage channels of the roofing above them (Fig. 5). At the present time the coffer has flat rectangular openings, two on each side; although we can imagine that originally maybe there was a series of small arches. The light that is transmitted through the vents of the vault penetrates through these openings, and gives marvellous illumination to the space next to the mihrā $b$.

27 Marçais, L'architecture musulmane d'occident, p. 196. 


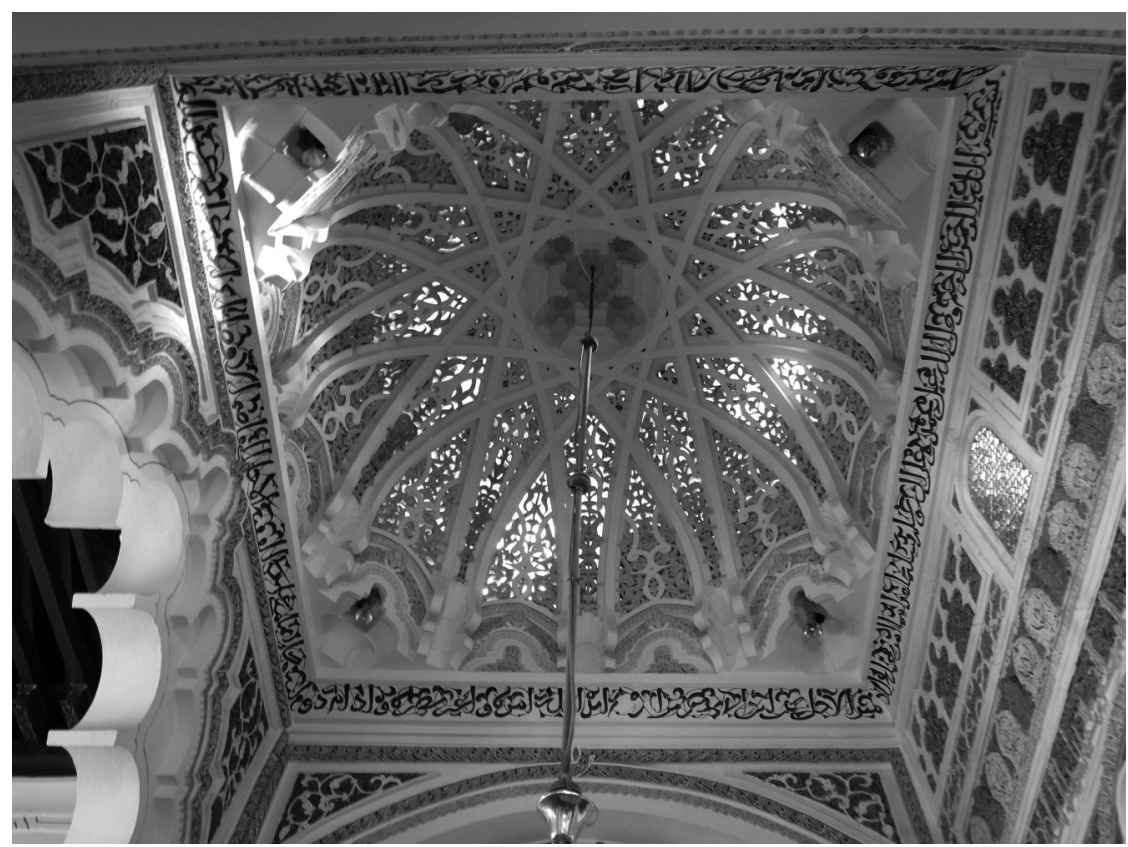

Figure 19. View of the dome covering the maqșūra (A. Almagro).

The twelve arches that make up the basic structure of the dome are all equal and start out from a cavetto that cantilevers only along its intrados. On the upper edge, and without any lack of continuity, a typical "serpentine" form begins, producing a type of thick tear that afterwards continues with a semicircular profile. The cavetto and the area with the sinuous outline conform the dome's rise while they also provide a slight horseshoe shape. The arches start practically from the vertices of a polygon of twelve sides. From these points, eight are practically on the edge of the cornice ${ }^{28}$ that is the support to the dome, while the other four, which coincide with the axes of the space, are situated much further inside. In this straightforward way we cross from the square plan to the dodecagonal which is really what the dome has. In fact the intradoses of the arches that start from the same point do so from a place that is slightly more advanced, therefore allowing an

${ }^{28}$ In fact some starting cavettos of the arches that lead from these vertices are on the edge and others are clearly projecting. 


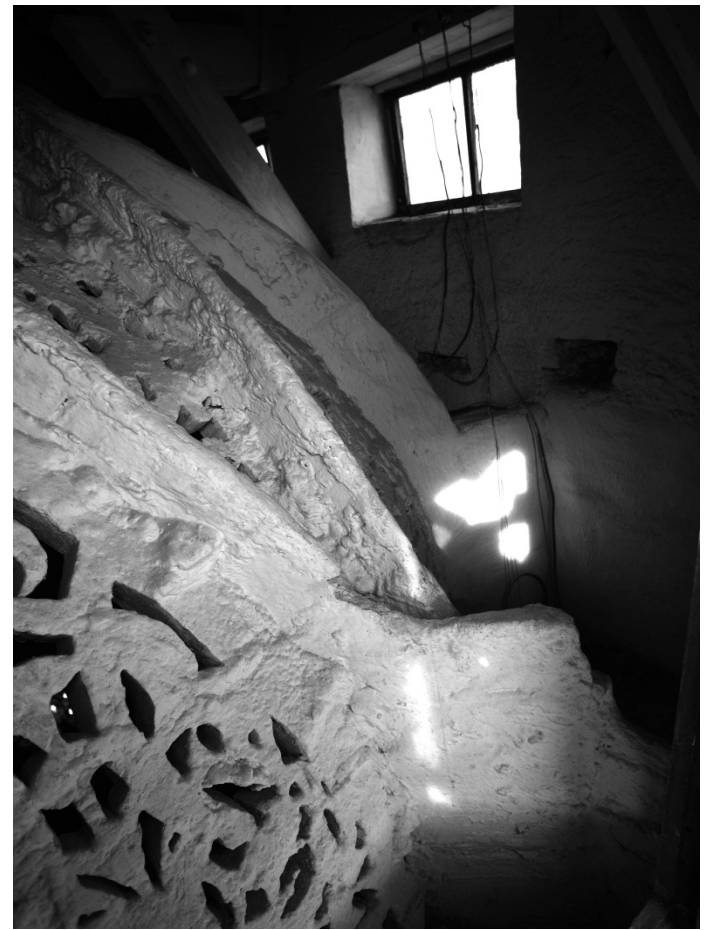

Figure 20. Detail of the extrados of the dome covering the maqșüra in the supporting area of the ribs (A. Almagro).

autonomous development without any macles being produced. In this way it can be said that the extradoses of these arches are the ones that start from the points of the star. Two arches set out from each point, each of which is perpendicular to each side of the polygon, therefore from each two adjoining vertices parallel arches lead out. This means that a twelve pointed star is formed (Fig. 12) and determines in its interior another dodecagon that closes with a cupola of muqarnas, as we shall see.

These arches are built with bricks arranged in line, joined by the sides that we consider to be the stretcher in a normal brick arrangement, as Marçais pointed out ${ }^{29}$ (Fig. 20). This means that the width of the intrados hardly reaches $7 \mathrm{~cm}$, equivalent to the thickness of the brick

29 Marçais, L'architecture musulmane d'Occident, fig. 126. 
together with the plaster on both sides which was left completely smooth. On the extrados of the dome the bricks have no plaster, although they are less clean than in those drawn by Marçais, since they have numerous lumps of plaster which reinforce their union with plates of web spandrel. The thread has the size of the brick together with the plaster of the intrados, which is about $30 \mathrm{~cm}$.

The arches leave between each other large spherical polygons of three or four sides on their lower part and other smaller ones in the vicinity of the central polygon, which constitute the web spandrels of the vault (Figs. 19 and 21). They are formed of plaster plates that have openwork and are decorated on the face giving on to the interior, with intertwining mixtilinear arches composed of plain palm leaves; they create a simple sebka filled with arabesques elaborately engraved and formed by digitate palm leaves. The layout of these arches interlaces with the ribs on passing from one web spandrel to another, which constitutes a second decorative order after the one composed

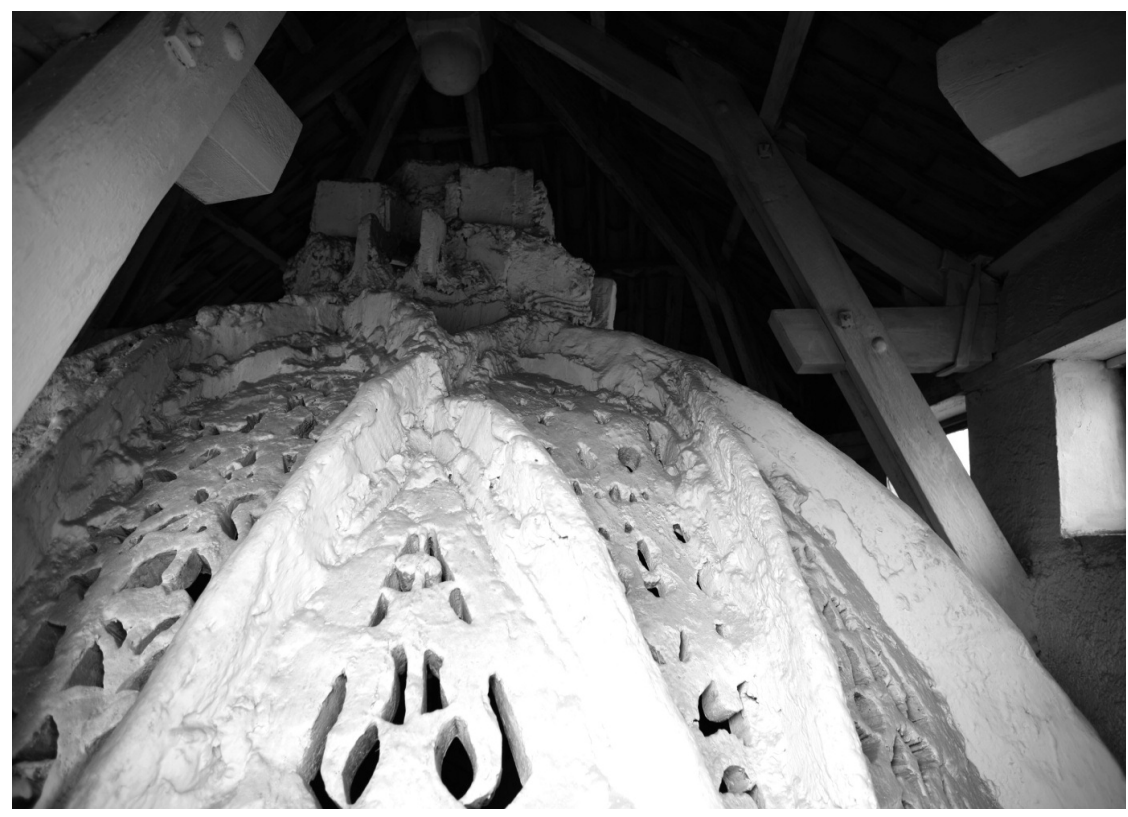

Figure 21. Detail of the extrados of the dome covering the maqșūra with the little top cupola (A. Almagro). 
by the intertwining arches. The third decorative order is created by the arabesques. In the first crown of web spandrels those of a triangular shape alternate with those of four sides. The latter appear between the ribs that start out from the same vertex of the plan and in their inferior vertex they have a small arch crowned by another ribbed one. Above this is where the arabesque decoration begins. The triangular web spandrels have their base on the epigraphic cornice and a mixtilinear arch also rests on it; the tympanum is filled in with arabesques except in the angles of the space of the maqșura where these arches constitute the front of a squinch of muqarnas that at these points resolves the move from the square plan of the lower space to the dodecagon of the vault. This solution marks a clear difference from what happens in the central dome of the mosque, which is later, and it is where some small flat roofs were placed, decorated with a single eight pointed star (Fig. 11). These squinches consist of three toothing pieces of a square section and cylindrical profile and two of a triangular plan and a central ribbed cupola with an eight pointed star layout. The result is therefore a very simple design and to a certain degree it is primitive. The mixtilinear arches at the base of the triangular web spandrels have a first archivolt with the same profile and another higher one with a pointed profile and the composition of sebka starts from this point.

The central cupola crowning the dome proves to be far more complex. It has four rows of muqarnas, the first one in a dodecagon plan, the second one square with an octagonal top formed of pieces of a rectangular section and cylindrical profile and four complex cupolas in the angles. The third one starts as an octagon and is crowned in an eight-pointed star and the higher one forms a ribbed cupola. This top dome constitutes one of the most ancient compositions of muqarnas by the Muslim West and already demonstrates a remarkable complexity announcing the solutions to be adopted from this time onwards. The cupola has a diameter of $1.07 \mathrm{~m}$ at base and a height of $0.86 \mathrm{~m}$. The total height from the ground is $9.65 \mathrm{~m}$ and the distance from there to the supporting cornice of the cupola is $6.30 \mathrm{~m}$.

As we have already mentioned, all the web spandrels have openwork from the empty spaces left by the arabesques, which allow the light entering through the windows of the coffer that protects the dome to reach the interior of the mosque, which creates a startling 
lighting effect. These plates must have been carved on the ground and they were later held in place by plaster between the nerves. The nerves project only 3 or $5 \mathrm{~cm}$ into the intrados, while they are much more patent in the extrados where, since they are not plastered, they appear in their true layout with the bricks linked together, as Marçais stated (Fig. 20).

Over the dome there is a space between this and the roof which is now perfectly whitewashed to transmit the light better towards the interior of the prayer room (Fig. 21). The present roofing is held up by a wooden framework and from the construction solutions we can deduce that it has been made very recently. It consists of four trusses with boards joined with thick screws and their corresponding nuts. Two trusses are supported on the centres of each side and the other two on the angles, according to the direction of the diagonals. Each truss consists of two rafters that are supported on a wall plate and they unite on the vertex in a thick central newel. The rafters rest on some struts that start much lower than the support of these and they join them at half of their length by means of a simple overlap supported by through bolts. Some tie beams join the support of the rafters with half of the struts also by means of an overlap fixed with screws. Two square section purlins rest on the rafters, and upon these a series of smaller rafters are placed at a distance such that they support the canals of the roof tiles doing away with the use if any planking whatsoever. The roof is made of curved tiles.

\section{The structure of the roof of the naves}

Another feature of this mosque is the conservation of an important part of the original structure of the roof of the prayer room, and in particular, that of the central nave. Marçais described the structure with special accuracy and drew it with skill, but in my opinion he did not get to the bottom of what we think was the original solution and what the later changes almost certainly were.

The original structure was formed of simple trusses with about 23 $\mathrm{cm}$ of separation and composed of two rafters and a tie-beam (Figs. 10, 12 and 13). We are unaware of how the union of the rafters with the tie-beam was solved, although Marçais draws the union of the 
rafters with half-wood joints without the presence of ridgepole..$^{30}$ This seems to have been the original layout in all the naves, to judge from the remains that are preserved, particularly in the first nave next to the central one on the east; in spite of having the majority of the tie-beams cut, the ends of many of them are still preserved which confirms this layout. In the central nave, due to its greater span, the tie-beams were supported by richly decorated corbels on both sides (Fig. 22). In accordance with the way in which the structure operates, these corbels had no true structural function, since the tie-beams, on working under traction, were not affected by their length, as if they had been if dealing with a panelled ceiling with the parts subjected to bending. Therefore it seems that the insertion of these corbels, which were richly decorated with arabesques, had a function that was more aesthetic than structural.

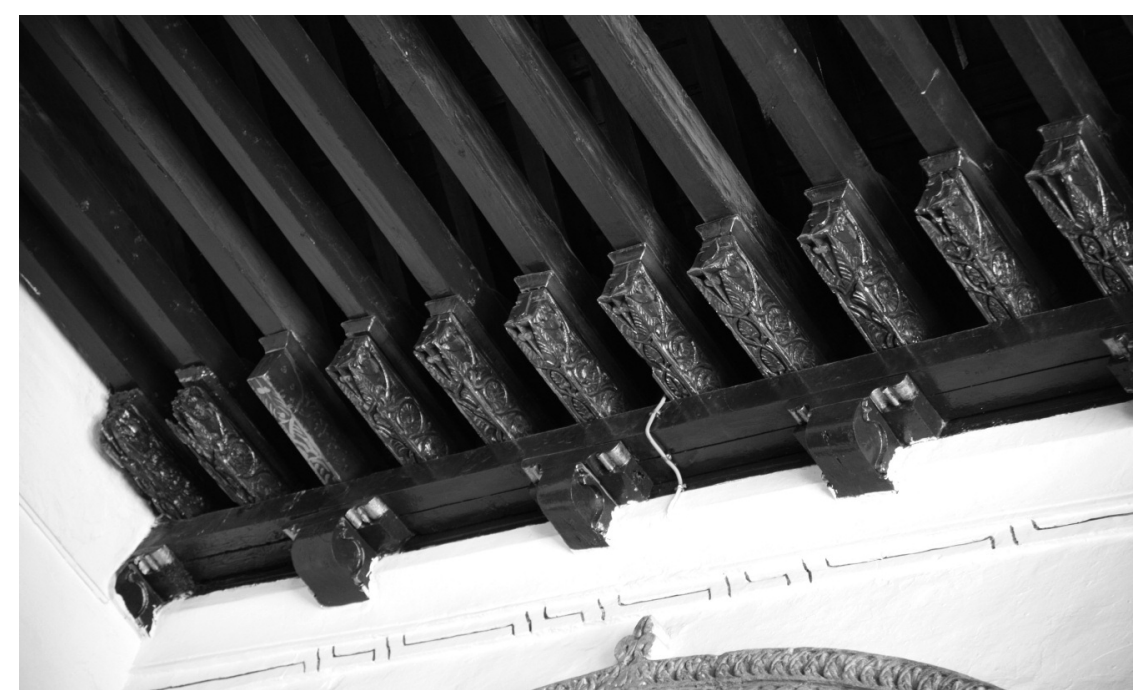

Figure 22. Detail of the support of the frame of the central nave (A. Almagro).

${ }^{30}$ Marçais, Album de pierre, fig. 20. Also in this detail of the union of the rafters (upper drawing in fig. 20) Marçais makes a mistake on drawing the joint line of the wood in a mistaken and impossible way, demonstrating that in spite of being a great draughtsman, due to his professional training as a painter in architectural subjects, and above all in constructional ones, his knowledge seemed to be limited. At present all the wood in the structure is covered with a thick layer of paint that seems to be an oil one or even synthetic enamel judging from the noticeable shine, which makes it almost impossible to know the details for assembling the parts. The decorated corbels also have imitation gold paint. 
Underneath the corbels there stretches a purlin lengthwise, formed of two pieces of wood attached to the wall that are supported every $0.85 \mathrm{~m}$ approximately on other corbels that have a quarter torus profile, and with very simple decoration, as they only have a simple side rabbet of serpentine shape. Between the corbels and the purlins there are some small footings formed of two parts, an interior one of prismatic shape and the other external one with a profile including plant apices. The most surprising element of this layout is not just that these lower corbels are hardly decorated, but that the purlins that are supported by them and which at the same time sustains the small corbels accompanying the tie-beams conceal part of the corbels' decoration. Furthermore the wooden structure is also situated over a cavetto that tops the portico and widens it in the upper part, with the aim of leaving more space for the roof drainage collector. What is also strange is that these lower corbels interrupt the cavetto from time to time, which would not be logical if this solution had been designed from the very beginning. In my view, the lower corbels and the lengthwise purlins are the result of some later repair work or reinforcement. Also due to this repair work, it seems, is the existence of another purlin that stretches lengthwise inside the vertex that forms the rafters and the tie beams. Marçais draws the rafters supported by a wall plate which in turn is based on the braces. This detail cannot be seen from the ground, although it would seem more logical if each rafter was assembled with the end of the tie-beam by means of a mortise and tenon effect, as it seems that the structure of the mosque in Cordoba was resolved. ${ }^{31}$ In any case, these purlins inserted between rafters and braces, which seem to be a replication of the wall plate, and that are fastened by means of decorated parts that are evidently of reuse of wood from a different place, since the cuts restrict the decoration, they also seem to correspond to a reform or reinforcement of the original structure.

We can infer from this information that the structure of the roof must have undergone repair work, maybe due to rotting of the heads

31 Wulf Barreiro, F., Origen y evolución de la carpintería de armar hispano-musulmana. De los antecedentes romanos, bizantinos y sirios hasta la carpintería almohade, Unpublished doctoral thesis. Department of Building Structures. Technical School of Architecture, Madrid, 2010, p. 286, fig. 87. Cabañero Subiza and Herrera Ontañon, "Nuevos datos para el estudio de la techumbre de la ampliación de al-Hakam II de la mezquita aljama de Córdoba", p. 279, fig.5. 
of the rafters and tie beams brought about by leakage from the channels for collecting water from the slopes of the roof above the porticos. To reduce the damage of the tie beams they decided to cut down the light between the supports, by means of placing a lower order of brackets with lengthwise purlins, and to avoid shrinking of the rafters due to rotting of their ends, they placed some purlins supported on the tie beams and attached by pieces of reused wood from other parts of the structure.

If we return to the subject of the shape which we suppose the original structure had, with a succession of trusses formed by two rafters and one tie beam, supported on both corbels of an equal section, we are presented with an identical solution to what there seemed to be in the hall of a palace which we imagine to be of Almohad times. Remains of it are preserved between houses 2 and 7 of the Patio de Banderas in the Alcazar of Seville ${ }^{32}$ and curiously it still maintains in one of the accompanying bedrooms a vault of interlaced arches very similar to what we have analysed earlier. ${ }^{33}$ These resemblances would enable us to review the dating of the remains from Seville which could also be attributed to the Almoravid period.

In the rest of the mosque the structures of the roof appear with diverse solutions. In the naves forming the porticos around the courtyard there is a predominance of frameworks of rafters without ridgepole and with spaced double tie beams. In the prayer room, we find both this solution and what seem to be remains of the original layout which would be similar to that of the axial nave, but without small corbels. In the adjoining nave to the east this solution can be seen, although there are quite a lot of tie beams that have been eliminated, having been cut near their ends, in spite of which their connection to the wall can still be observed. Here there are also purlins placed next to the vertex, forming the rafters and tie beams and a wall plate that also stretches as a base for the tie beams, slightly projecting and supported on wood pieces that act as slightly cantilevered corbels set at regular intervals. But here the wood pieces are placed on top of the cavetto, without interrupting it, contrary to what occurs in the central nave.

32 Almagro, "La documentación planimétrica de los monumentos de Sevilla inscritos en la lista del Patrimonio Mundial," pp. 89-90, fig. 7.

33 Almagro, "Sistemas constructivos almohades: estudio de dos bóvedas de arcos entrecruzados," pp. 48-51. 


\section{The minaret}

We do not know if the original Almoravid mosque had a minaret. Neither has the mosque of Algiers preserved any similar structure from this period. We owe the construction of the present minaret (Fig. 8 and 23) to the first 'Abd al-Wādid sultan, Yaghmorasan, as stated in the History of the Beni Zeyan by Mohammed al-Tenessy, as quoted by Brosselard. ${ }^{34}$ According to this, on reproaching him for not having written an inscription with a record of his sponsorship, the sultan would have replied with a simple sentence in the Berber language: "God knows." The tower is prismatic in form, with a square plan of $6.20 \mathrm{~m}$ each side and 24.75 high, crowned with staggered battlements, following the Andalusi traditions. On top of this first part of the tower there is another of smaller dimensions: $2.95 \mathrm{~m}$ in width and $6.30 \mathrm{~m}$ in visible height housing the landing of the staircase in the higher terrace of the first part. Internally the tower has a square staircase that rises rotating around a large central buttress in the counter clockwise direction. The four faces of the minaret are decorated according to the frequent compositions of western Islamic art, with their origin in the minaret of ${ }^{\circ} \mathrm{Abd}$ al-Rahmān III of the Mosque of Cordoba, but in this case there are obvious Almohad contributions. A large panel on either side contains a stretch of sebka (strap-work) that starts with small blind arches with a mixtilinear profile held up by columns without a capital. On the upper part, between two imposts of a straight section inlaid with tiles, there runs a frieze of five small blind lobed arches of a narrow cross-section that interlace with the band that forms the alfiz, making nodes in the keystone. Although the sebkas of the four sides are apparently similar, there are slight variations among them, mainly due to irregularities whose existence is difficult to explain. The greatest differences are to be found on the south and east sides. In the first, the start of the sebka is done from four arches, the left of which is disproportionately wider than the others, and therefore this produces irregularities in all its development, as can be seen in the drawing (Fig. 23). This wider arch has a span very similar to that of the arches on the eastern side, where there are only three. On that side, because the sebka starts from only three arches, they are logically wider than those of the other faces, so

${ }^{34}$ Brosselard, "Les inscriptions arabes de Tlemcen," p. 89. 
the sebka is more open and uneven. It is interesting that on this side the columns supporting the arches do in fact have capitals, which leads us to think that in the other columns they should have existed too but they may have disappeared because of deterioration on being made with mortar. The decoration on the northern face has a similar composition to the western one starting at its base of four arches (Fig. 4).

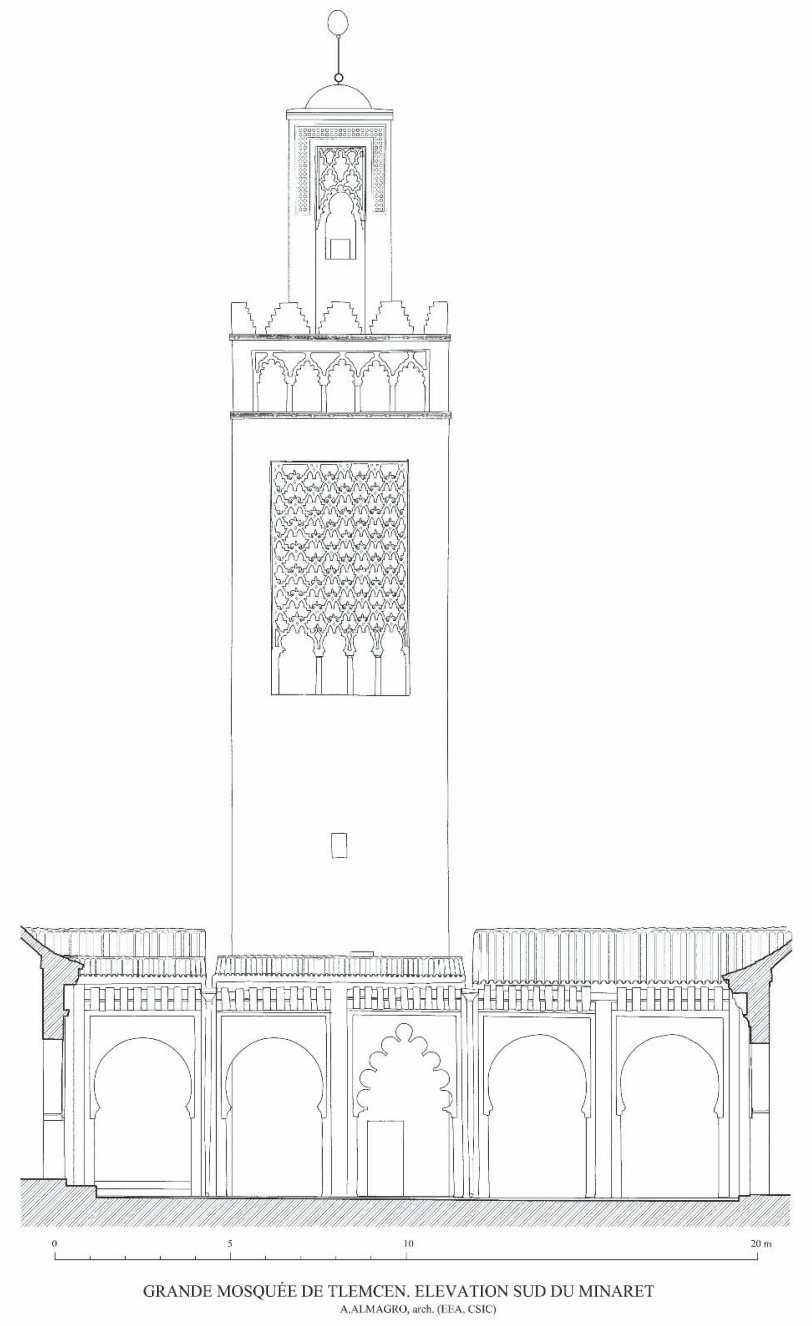

Figure 23. Southern elevation of the minaret and of the courtyard portico of the Great Mosque of Tlemcen (A. Almagro). 
It turns out to be difficult to give a logical explanation for all these irregularities. From my point of view they could be due to two causes: a lack of skill on the part of the builders ${ }^{35}$ or to restoration work badly carried out. Neither justification is really acceptable. It is not likely that the builders of a work of this importance, apparently well performed should have been so incompetent when reassessing such a frequent decoration in the architecture of this period. Nor is it easy to explain these anomalies as the result of a badly performed restoration. In the engraving by Berbrugger ${ }^{36}$ it seems that deterioration of certain importance can be appreciated in the decoration of the minaret, however I do not believe that this can justify the considerable deformations now visible since they affect the whole design of the sebka, nor can we deduce what would have been the correct solution to apply. Another explanation would be to think that on the southern side they began to lay out the decoration the same as on the eastern side, with a starting composition of only three arches and that during the erection of the decoration they decided to change to a composition of four. I must acknowledge that this explanation is not very convincing either. In any event, these questions have been outlined above.

The upper part of the tower reveals a rather richer decoration, with a blind horseshoe arch flanked by another arch of lobes from which there starts a sebka also formed of oblique lobed branches. All of this is inserted into a cavity of vertical proportion that is accompanied in its upper part by a panel of tiles which forms a framework on three sides. An impost crowns this higher part of the building which is also decorated by tiles, above which protrudes the extrados of a cupola with a scant rise. The minaret is lacking in the typical jamūr made up of decreasingly sized spheres, and has only one rod at the end of which there are metallic rings.

\section{Geometry and layout}

As happens in the majority of architectural work, the great mosque of Tlemcen shows elements of composition based on geometry.

35 We should emphasize the difference of the most caring composition and fulfilment that can be appreciated in the minaret of the mosque of Agadir, which was the original Idrīsid foundation of Tlemcen, whose date we can imagine was somewhat earlier.

${ }^{36}$ See supra note 2. 
Marçais had already presented some hypotheses with regard to the geometrical layout of certain elements, ${ }^{37}$ but as he used input data that was not very trustworthy, his sketches presented considerable differences with respect to reality, we therefore consider it is essential to review and extend them.

The original ground plan of the mosque must have had as the base of its composition, similar to what happened in Cordoba, which we have indicated previously, a square divided into two parts which are practically equal, one intended for the prayer room and the other for the courtyard, although the latter proves to be incomplete due to the presence of the old palace (Fig. 17). The prayer room is at the same time divided into another two equal parts because of the presence of a transversal portico (Fig. 18). In the original layout of the mosque, in the half nearest to the wall of the qibla, an area spatially more diaphanous was also specified since it is supported by columns instead of pillars, which would maybe function as maqșura, and which occupies an area of a square ground plan (Fig. 17). This solution can be assumed to be a precedent of that which was adopted in the mosque of Mansūra almost three centuries later. ${ }^{38}$ We can also visualize the shape of the façade of the prayer room towards the courtyard of this first oratory (Fig. 24) recovering the symmetry of the present façade on eliminating two arcades of the western side that give clear signs of having been attached to the pre-existing façade in which the original buttresses are shown. This leads us to imagine the dimensions of the courtyard with a rectangular shape, not so elongated as that of Cordoba but more similar to the proportions of the Great Mosque of Algiers. ${ }^{39}$

From a decorative point of view the most important composition is revealed in the façade of the mihrāb. However, the setbacks we have described here of the construction process have no doubt entailed difficulties and anomalies when establishing a regulatory system of its layout. Therefore it turns out to be difficult to define clear relations between the dimensions of the arch of the mihra $\bar{a} b$ and the rest of the façade since there do not seem to be measures or relationships between

37 Marçais, Album de pierre, figs. 10, 11 and 13.

38 Charpentier, "Tlemcen et l'évolution des modèles," p. 149; Terrasse, "L'esthétique tlemcénienne," p. 251.

39 Marçais, L'architecture musulmane d'Occident, p. 191. 

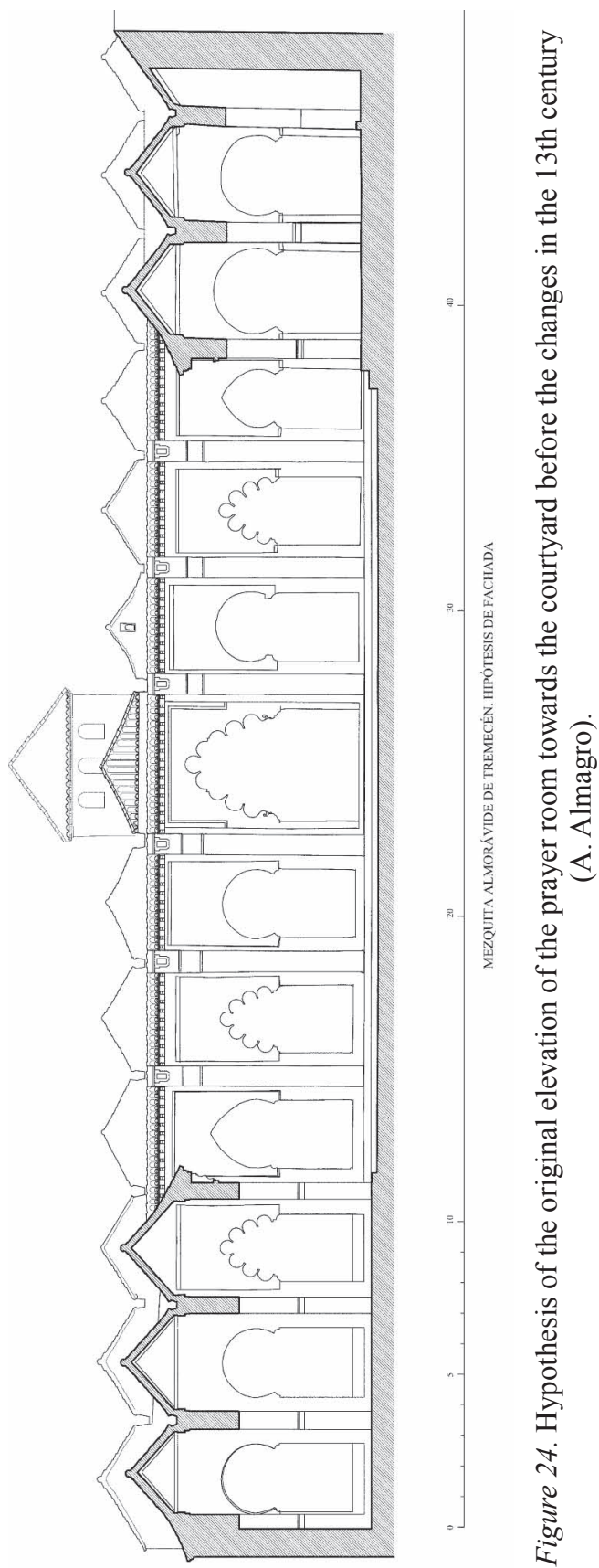

Al-Qantara XXXVI 1, 2015, pp. 199-257 ISSN 0211-3589 doi: 10.3989/alqantara.2015.007 
them, except that they share the same axis (Fig. 25). The opening of the mihra $\bar{b}$ has a width-height proportion of $1 / 2$. Its arch extends to form the horseshoe shape equivalent to $2 / 3$ of the radius. ${ }^{40}$

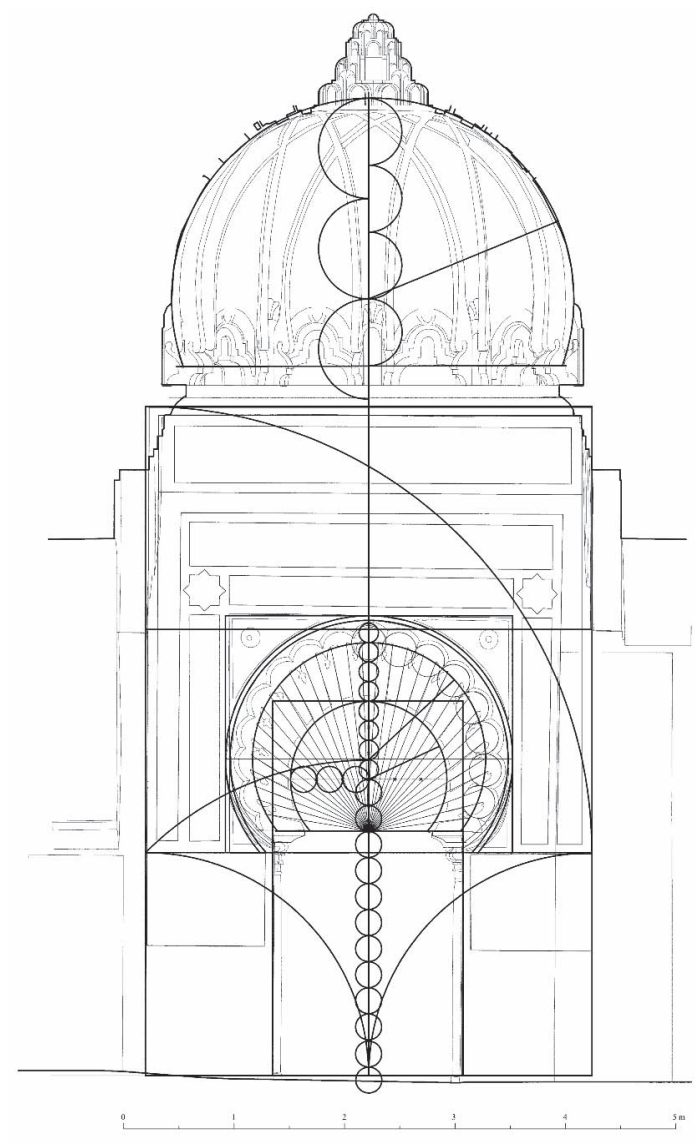

Figure 25. Lay out of the façade of the mihrāb (A. Almagro).

40 This relationship is greater than that adopted in the majority of the Andalusi caliphate arches, although it is somewhat less than the one we can observe in those of the 11 th Century in the Aljafería and the Alcazaba of Malaga (Camps Cazorla, Modulo, proporciones y composición en la arquitectura califal cordobesa, pp. 89-92, figs. 50-54) Marçais sketches it and extends it 5/7 of the radius (Marçais, Album de pierre, fig. 13) which gives a line of imposts lower than is real. 
The façade where the mihrāb opens has a width height proportion of $2 / 3$ including up to the supporting cornice of the dome. The first third of this height marks the end of the jambs of the arch of the mihrāb underneath the line of the imposts, and the beginning of the most lavishly decorated area that occupies a square area. The arch of the mihrāb shows the extrados line to be off-centre with regard to the intrados, displaced $1 / 4$ of the dimension of the radius of the intrados. The joints of the voussoirs converge at a point situated on the line of imposts. At a distance equivalent to $3 / 4$ from the radius of the arch of the $m i h r a \bar{b} b$ and concentric with the archivolt of the extrados a circle is defined containing the centres of the lobes that accompany the ends of the voussoirs. These circles are tangent between each other and enable us to determine their axes. The radius of the archivolt that defines the extrados of this arch is somewhat larger than twice that of the intrados. This archivolt presents a different curvature in the area of prolongation under the centre, closing the aperture of the arch in a disposition that proves rather unusual.

As we pointed out, the profile of the dome is prolongated over the line of imposts that define the beginning of the cavettos of the arches that shape it, to $1 / 3$ of its radius, although its horseshoe shape is partly hidden by the serpentine form with which those arches start. The centre of the dome is situated at a height of approximately $1 / 2$ of its radius above the cornice that supports all the structure.

Despite the fact that these correlations might have served for the composition of the structure and its decoration, there are small differences between these theoretical designs and reality. They are differences that we can attribute both to errors in the fulfilment and to deformations undergone by the structure. Also certain anomalies that we can observe in the whole layout seem to confirm that this had to adapt itself to realities that already existed. The shape and layout of the mihrāb bear no precise relationship with the decoration accompanying it, which would confirm two different times of implementation. Hence the decoration that accompanies the arch had to be adapted not only to its pre-existence, but also to the irregularities that there were in other elements, such as the decentralization of the small upper window or the existence of two doorways on either side of the niche. All this would lead to a plan with what was pre-existing and the absence of a real regulatory plan which all the composition complied with. 
We have already mentioned the geometric design of the arches of the dome that covers the space before the mihrāb, which form a twelvepointed star whose points are on a circle within which the square of this space is inscribed. From each point there are two arches that go up as far as the points adjacent to the symmetrical opposite (Fig. 26).
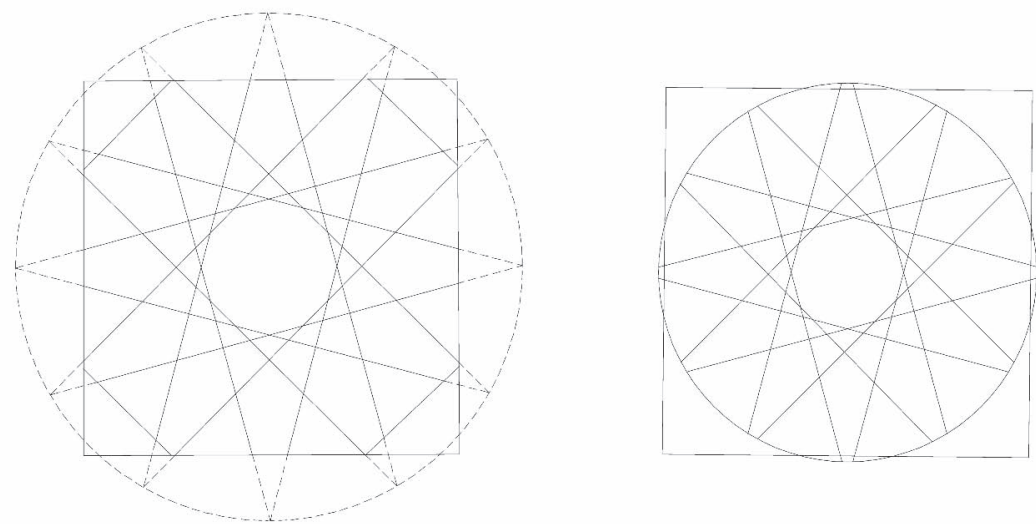

Figure 26. Geometric lay out of the ribbed domes of the Great Mosque of Tlemcen. On the left the one preceding the mihrā $b$ and on the right the one situated in the centre of the prayer room (A. Almagro).

The other elements of the mosque that are attributable to geometric plans offer a remarkable variety of solutions in their design, therefore demonstrating the great freedom that their architects worked with (Fig. 27). So the lobed arches are not only differentiated by the number of lobes or by the shape of their starts (in simple cavetto or with a "serpentine" element), but the noted guidelines of the arches show numerous variations in the situation of their centre as well as different degrees of aperture and alignment of them. As an example we have the two arches of 11 lobes in the central nave: in the arch of the central portico of the prayer room the centres of curvature would be separated $8 / 10$ from the span, while in the access to the maqșüra that separation would be $12 / 10 .{ }^{41}$ We can also find differences in the prolongation of the

${ }^{41}$ Marçais (Album de pierre, fig. 11) situates them at10/10, no doubt based on an inaccurate sketch. The sketch of the arch in the centre of the room (fig. 10) is much closer to reality. 

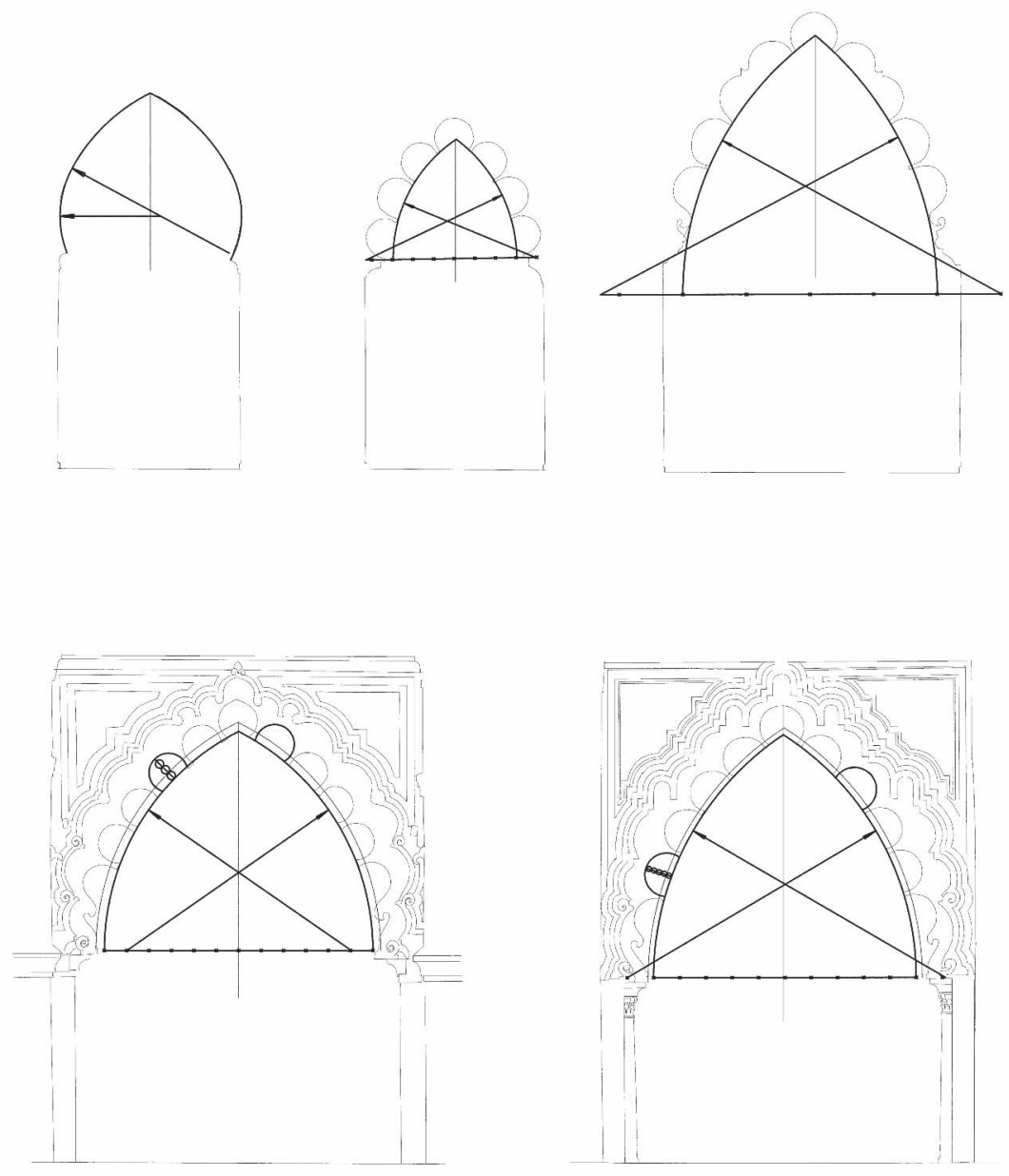

Figure 27. Geometric lay out of the different arches of the Great Mosque of Tlemcen (A. Almagro).

horseshoe of the lobes which varies between $1 / 2$ and $1 / 3$ approximately of the radius. In these cases we should also point out the existence of irregularities which might be due to both errors in construction and to deformation or seating suffered by the pillars that produced deformations in the arches as well. 


\section{Parallels}

The Great Mosque of ancient Tagrart, the Almoravid foundation that became present day Tlemcen, constitutes the archetype of the mosques of this period, with a prayer room of 13 naves that are perpendicular to the qibla wall formed of series of six circular horseshoe arches, which are braced by another transversal arcade of lobed arches. Originally it must have had a courtyard similar in surface area to that of the prayer room, no doubt in search of analogous proportions to the first Great Mosque of Cordoba built by 'Abd al-Rahmān I. As it seems to be well established that the dome which covers the space next to the mihrā $b$ was added at a later date, we can contemplate the hypothesis that in this first mosque there existed an area that was spatially more diaphanous since it had columns instead of pillars in both porticos of the central nave that formed a great maqșüra which was highlighted by the arches of the cross-section portico that gives on to this space, which has a greater number of lobes than the rest.

The construction of the dome in front of the mihrāb no doubt inspired by the solution adopted in the enlargement of al-Hakam in the Great Mosque of Cordoba, defined a much more reduced area of maqșura, which was also delimited by a rich wooden lattice fence (Figs. 28 and 29). The presence of this dome altered the original composition by emphasizing an enhanced vision of the mihra $\bar{b}$, a phenomenon that was already present in old mosques such as al-Aqșā in Jerusalem and that of Qayrawān, which was nearer in time and location to this one. However, this dome is undoubtedly directly inherited from the domes covering the maqșüra of the great Caliphate extension of the Great Mosque of Cordoba when adopting the system of interlaced arches already present in other constructions of Andalusi such as the mosque situated next to Bāb al-Mardūm in Toledo (Fig. 30). But it also included another new development which, although it has not been widely disseminated, entailed a change in quality in the spatial structure, which was to make the vault radiate light; therefore increasing visual attraction towards the mihra $\bar{b}$ whose front was enhanced by abundant decoration. This transformation in quality bestowed an outstanding value to the dome. In contrast to Qayrawān or Cordoba where the light enters through small openings in the vertical walls, here the illumination, thanks to the whitening of the existing space above the vault and facilitated by the orifices that exist, seems to arise from the whole surface, and generates 
a light atmosphere of enormous perceptive quality. This is the first case that is preserved with this arrangement, although there are references to the existence of a vault of similar characteristics in the western bedroom beside the Golden Hall in the palace of the Aljaferia in Zaragoza. ${ }^{42}$ This was built in the $11^{\text {th }}$ century, and there is a fragment of plaster arch from here preserved in the National Archaeological Museum in Madrid as well as an openwork web spandrel from Zaragoza Museum. ${ }^{43}$ In this case the arches had a section more similar to the vaults from Cordoba than in that of the fragile subtlety of the vault of Tlemcen.

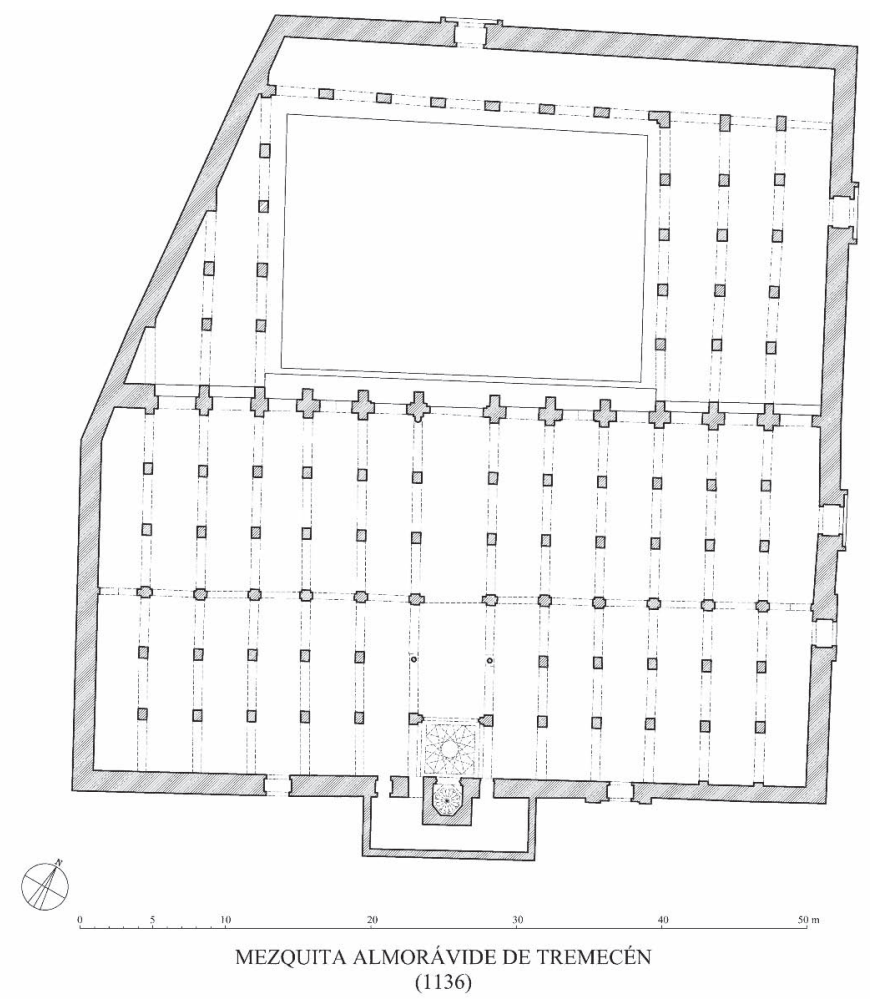

Figure 28. Hypothetical ground plan of the Great Mosque of Tlemcen after the construction of the dome of the maqșüra by 'Alī b. Yūsuf in 1136 (A. Almagro).

${ }^{42}$ Gómez Moreno, El Arte árabe español hasta los almohades. Arte Mozárabe, fig. 29.3

43 Gómez Moreno, El Arte árabe español, fig. 293; Torres Balbás, "Bóvedas caladas hispanomusulmanas," p. 103. 


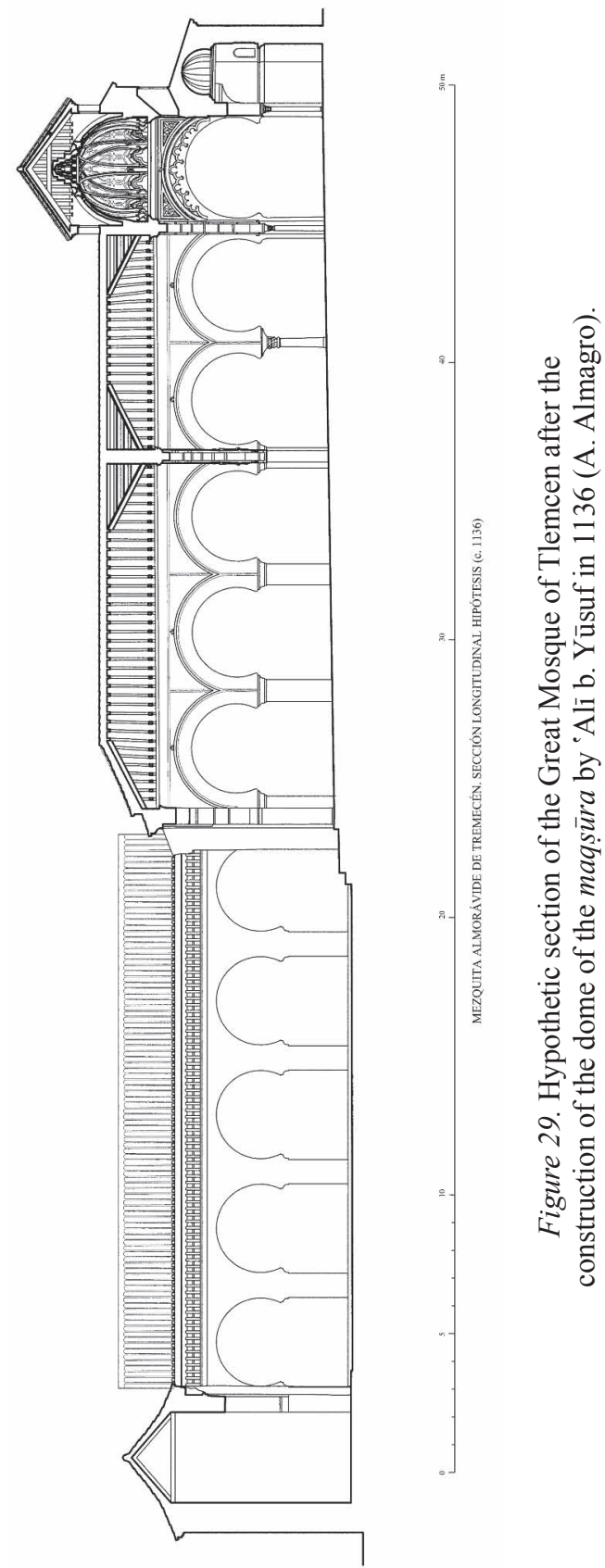

Al-Qantara XXXVI 1, 2015, pp. 199-257 ISSN 0211-3589 doi: 10.3989/alqantara.2015.007 


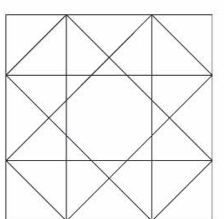

Mosque of Cordaba Caliphate vault of the maqsura

XY
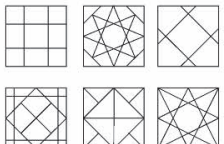

Mosque of Bab al-Mardum

Toledo

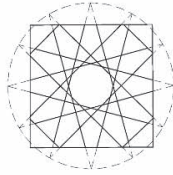

Mosque of Tlemcen Almoravid vault

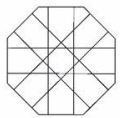

Minaret of the Kutubiyya mosque Almohad vault

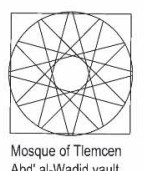

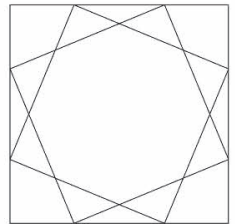

Mosque of Cordoba

Caliphate vault beside the mihrab

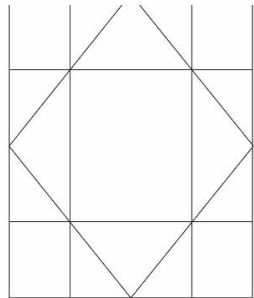

Mosque of Cordoba Caliphate vault at the begining of the nave

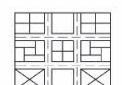
Mosque of Tornerias Toledo

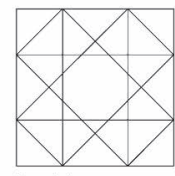
Qarawiyyin mosque Almoravid vault

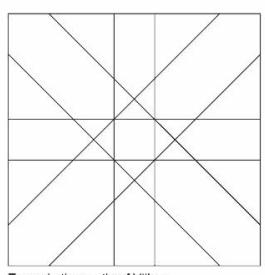
Tower in the castle of Villena Ground floor

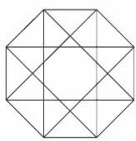
Palaces of Galiana Toledo

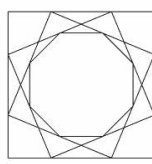
Qubba Barudiyyin Fez Tower in the castle of Villena First floor

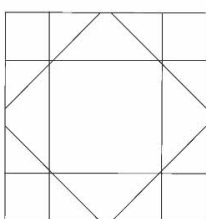

Mosque of Cordoba Vault of the Royal Chape

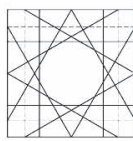
House in the Banderas Courtyard Alcazar of Seville
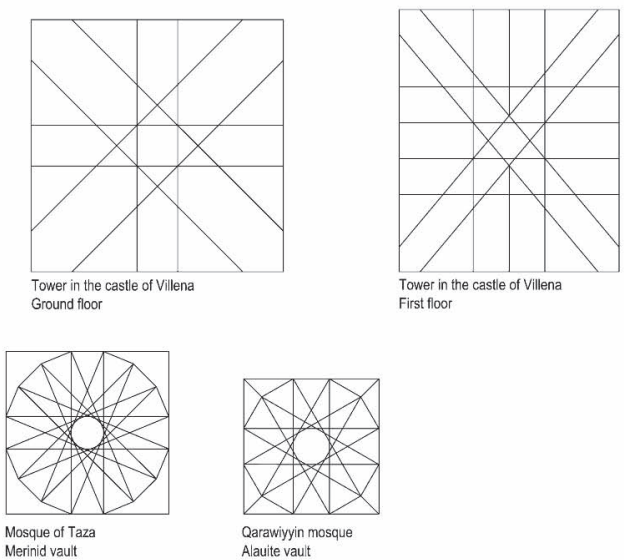

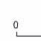

5 $20 m$

Figure 30. Geometric lay outs of the vaults of the interlaced arches of Al-Andalus and the Maghreb (A. Almagro). 
The resemblance of the mosque of Tlemcen with the Aljaferia is not merely reduced to the openwork of this alleged vault, but there are some decorative elements that have great resemblance, as already indicated in the case of the arches supported by imposts that are lacking in sustaining element. These were widely used in the palace in Zaragoza and their appearance in the side arches that support the vault in Tlemcen lead us to associate it with a direct affiliation ${ }^{44}$ (Fig. 13). The same could be said of the arches of the higher frieze on the front of the mihrāa (Fig. 14) that have very stumpy proportions, reminding us of the frieze preserved in the above-mentioned museum in Madrid, probably from the Golden Hall. ${ }^{45}$

We should recollect that the openwork vaults were later very well received in Spanish architecture and they found numerous examples of vaults which allow light to enter between the ribs, particularly in the vaults built in the late Gothic period. ${ }^{46}$

This vault also initiates the path of a group of ceilings that are lacking in a true tectonic character and that are only useful to shape the space, as they only maintain themselves, as there is another higher structure to support the roof. Although this characteristic already existed in vaults in Cordoba, in Tlemcen the character of a purely decorative element is accentuated by the lightness of the structure of the ribs. More or less contemporary with this vault is the one that covers the pavilion of mida' $a$ in the Almoravid Great Mosque in Marrakesh, the Qubba Barūdiyyinn, ${ }^{47}$ whose ribbed dome is also meticulously decorated, but is clad with another higher structure that is much more resistant and much thicker. The structure in the nave of the mosque Qarawiyyin in $\mathrm{Fez}^{48}$ has the same features, but in this case it is composed of only eight ribs of circular horseshoe profile and with smooth web spandrels. This shape of vault has given rise to other subsequent examples, such as the supposed Almohad one in the house of the Patio de Banderas in the Alcazar of Seville (Fig. 31). Due to its great resemblance to the one we are analyzing here, it might even be Almoravid; the vault of the last chamber of the minaret of the Kutubiyya mosque in Marrakesh (Fig. 32), is undoubtedly Almohad, or the later

${ }^{44}$ Ewert, Spanisch-Islamische Système sich Kreuzender Bögen, Ab. 24.

45 Gómez Moreno, El Arte árabe español, fig. 286.

46 Torres Balbás, "Bóvedas caladas hispanomusulmanas," pp. 195-198.

${ }^{47}$ Meunié, Terrasse and Deverdun, Nouvelles recherches archéologiques à Marrakech, pp. 21-36, figs. 14, 16, 20, 22.

48 Terrasse, La grande mosquée al-Qaraouiyin à Fès, Pl. 27. 

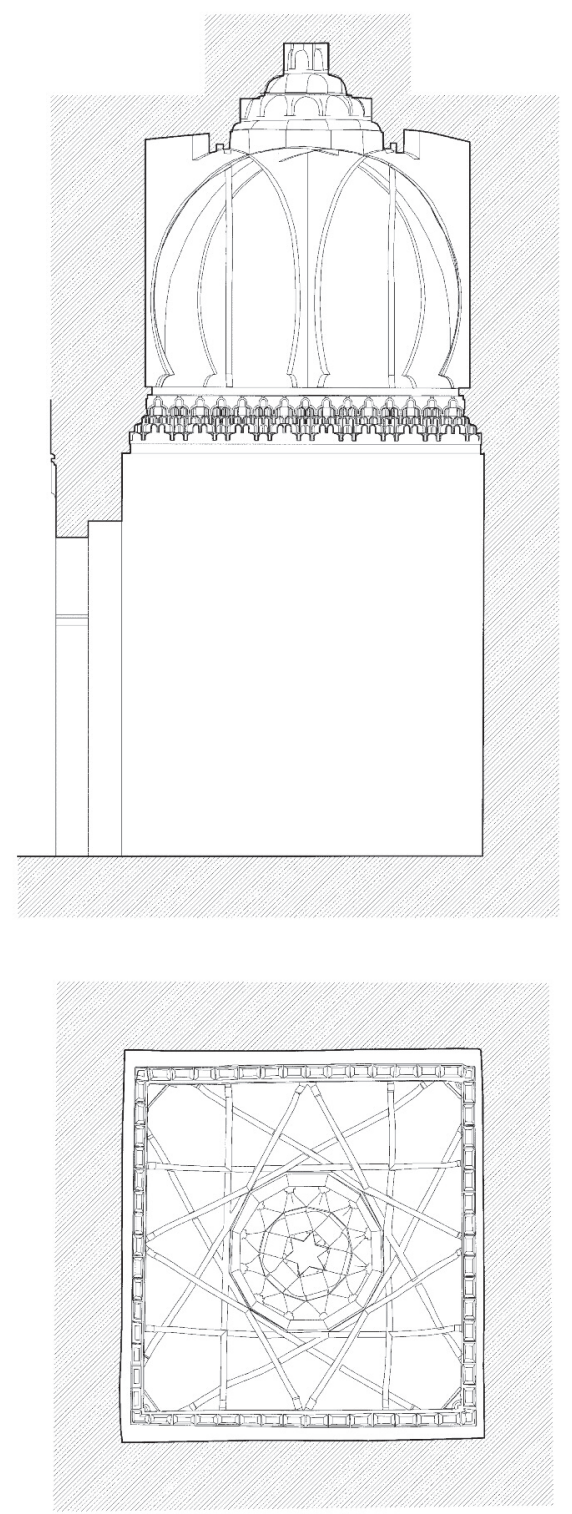

BÓVEDA DE ALCOBA EN CASA DEL PATIO DE BANDERAS DEL ALCÁZAR DE SEVILLA

Figure 31. Dome of interlaced arches of house $\mathrm{n}^{\circ} 2$ of the Patio de Banderas in the Alcazar in Seville (A. Almagro).

Al-Qanțara XXXVI 1, 2015, pp. 199-257 ISSN 0211-3589 doi: 10.3989/alqantara.2015.007 


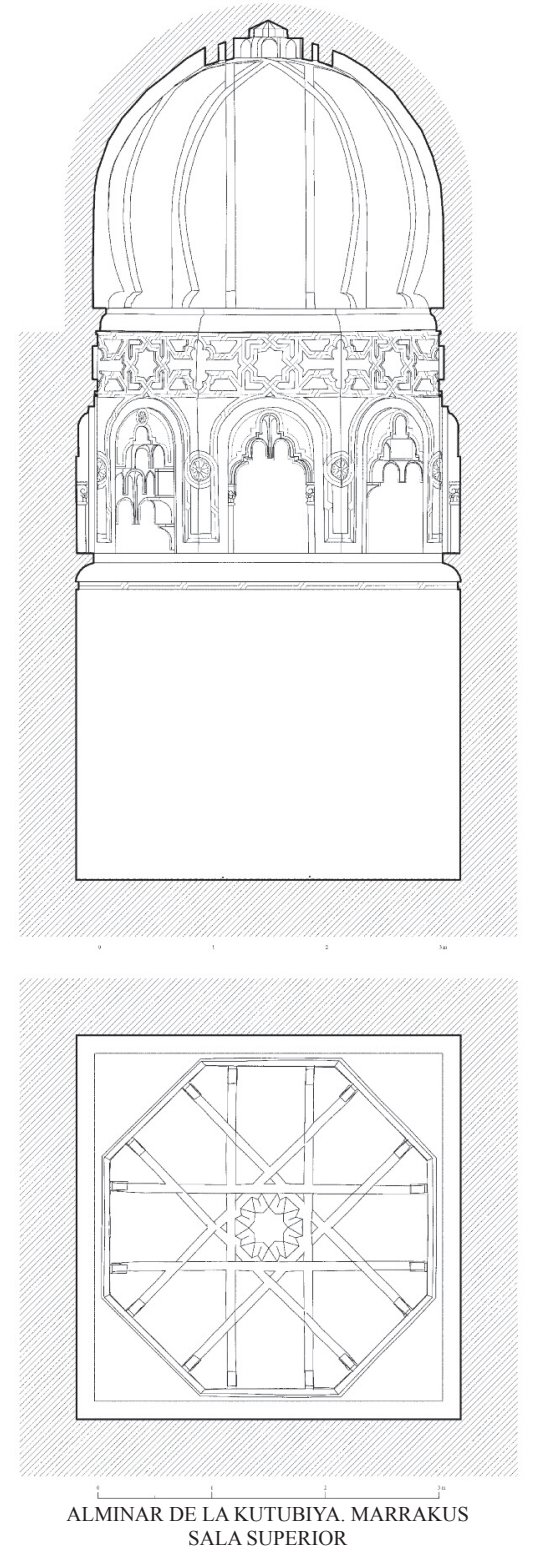

ESCUELA DE ESTUDIOS ÁRABES. CSIC. A. ALMAGRO/Arq. JUNIO 200

Figure 32. Dome of interlaced arches on the last story of the minaret of the Kutubiyya mosque in Marrakesh (A. Almagro).

Al-Qantara XXXVI 1, 2015, pp. 199-257 ISSN 0211-3589 doi: 10.3989/alqantara.2015.007 
one in the mosque of Taza, that occupies a similar position to that of Tlemcen in front of the mihrā $b$. The one covering the Royal Chapel of the cathedral, the ancient mosque, in Cordoba, also follows the same principle.

In the later vaults, such as the Marinid one of Taza $^{49}$ and that in the second section of the nave in the Qarawiyyin, ${ }^{50}$ from the 'Alawi period, and which follow similar lines of composition, it is possible to assess lesser relief in the ribs and, particularly, the loss of rise due to the fact that the arches are now not horseshoe but semicircular, which gives the dome a lower profile. A similar development can be observed in the central dome of the prayer room in Tlemcen, the construction of which we attribute to Yaghmorasan (Fig. 11). These vaults begin a tendency to treat the ribs as a mere adornment more than as structural elements. In this respect we should emphasize the resemblance that the architectural domes show in their respective photographs and the ones contained within the lamps which there are in some of these mosques. ${ }^{51}$ This trend will be fully formalized in the Christian funeral chapels built imitating the qubbas and in which the arches become mere decorative elements attached to the shell of the dome ${ }^{52}$ with an appearance closer to a carpenter's work than to brickwork

If we carry out an overall analysis of the different geometrical solutions used in the design of all these domes (Fig. 30), we can see that the dome of Tlemcen occupies an intermediate place, both because of its chronology and the complexity of its design. We can assume that the complexity of the geometry becomes more accentuated with the advance of time, because undoubtedly the simplest ones are the oldest ones in the mosque of Cordoba. The $11^{\text {th }}$ century domes take on an increased complexity and construction, emphasizing the great variety of models that are developed in the mosque next to Bāb al-Mardūm in Toledo. The Almoravid domes of Fez and Marrakesh are direct copies of the models of Cordoba but in the case of the dome of Tlemcen an increasingly complex design begins, and also therefore the lightness of the structure, later continued in the dome of Seville, whose dating

49 Terrasse, La grande mosquée de Taza, pp. 45-47, Pl. LXVIII-LXIX.

50 Terrasse, La grande mosquée al-Qaraouiyin à Fès, p. 34, Pl 27.

51 Terrasse, La grande mosquée al-Qaraouiyin à Fès, Pl. 105; Terrasse, La grande mosquée de Taza, Pl. LXXXV-LXXXVI.

${ }_{52}$ López Guzmán, Arquitectura mudéjar, pp. 173-177. 
is today still doubtful, although we could contemplate the end of $11^{\text {th }}$ century. The Almohad domes are apparently less complex than the previous ones, and preferring the play of cross-linking of pairs of parallel arches that follow the orthogonal direction to the sides and to the diagonals on the ground plan. We should highlight the set of vaults in the tower of the castle of Villena, ${ }^{53}$ where the tectonic character of ribs and web spandrels is fully recovered, necessary because of its supportive function and its dimensions. The later ones, from Marinid, 'Abd al-Wādìd and 'Alawì times are those that show further complexity, resorting in all cases to the star shapes with at least 12 or 16 points, but following the same scheme of the dome in front of the mihrāb of Tlemcen, joining each vertex with the two adjacent ones to the opposite. In the central dome of the prayer room that we are studying, attributed to Yaghmorasan, it is obvious that it is a copy of the one built by 'Ali $b$. Yūsuf, although in this case the points of the star are in a circle inscribed in the lay out. The domes of Taza and of the Qarawiyyin prove to be variants of this one, the former with more points and the latter turned slightly and inscribed in the square of the ground plan.

One of the aspects that is worth emphasizing in these observations is the remarkable variety of compositional solutions that were adopted and the very modest number of cases in which previous solutions were copied, and in these cases it could be assumed that the reason was more due to a desire to emulate the models as a way of recognizing their architectural and unquestionably symbolic value than to a lack of creative resources. So the models imitated are principally those of the mosque of Cordoba, particularly its dome in front of the mihrāb, which was repeated in the same position in the mosque of Bāb al-Mardūm and in the Qubba Barūdiyyin. The other model used in the other two domes of the maqșüra of Cordoba was used in the chapel of Bethlehem in the ancient Taifa palaces in Toledo and in the dome from the Almoravid period in the mosque Qarawiyyin. We have already mentioned that the model of Tlemecen is manifest in the two domes of this mosque, with minor variants. We can affirm that the rest prove to be combinations or innovations.

The dome of the maqsūra in Tlemcen also possesses the feature of having openwork and allows light to pass through from the upper

53 Almagro Gorbea, Soler Estrela and Soler Verdú, "La torre almohade de Villena (Bilyana) y sus bóvedas de nervios entrecruzados. Análisis formal y constructivo." 
space. To this effect there is the combination of light from the window above the mihrāb and possibly that which comes from the three small arches in the background of the mihra $\bar{b}$, which would accentuate the vision, as this would create an exceptional point of attraction towards the niche flooded with light. The light effect that this brings no doubt had an important symbolic motivation that would be present in the origins of this creation. The significance of the dome in Muslim cosmology and eschatology, inherited from previous civilizations, is well known ${ }^{54}$ and the reference to light as an attribute of divinity ${ }^{55}$ and its environment are undoubtedly reasons for the use of this procedure in this outstanding architectural masterpiece. If we imagine that the small cupola of muqarnas crowning the dome can be interpreted as symbolization of divinity expressed by means of an abstract conception controlled by geometry, the foundation that supports it is solely light, taking into account the description of the medieval text of The Scale of Muhammad. ${ }^{56}$ The light not only emphasizes the focal point of the space in the prayer room, but it also establishes a reference to divinity as it is bound to shapes controlled by geometry.

The dome of Tlemcen constitutes a historic milestone in the origin and evolution of a typology of constructions that assumed a strong foothold and development in the Islamic West. In spite of the fact that its conceptual and formal origin continues to be subjected to discussion, its clear differentiation with regard to eastern works of similar characteristics gives it a personality of its own and an outstanding place in the history of Islamic art.

${ }^{54}$ Papadopoulo, El Islam y el Arte musulmán, pp. 249, 251; Cabanelas Rodríguez, El techo del salón de Comares en la Alhambra, pp. 81-90.

${ }_{55}$ Although the relationship between light and divinity is interpreted in different ways by Muslim scholars and philosophers (Puerta Vílchez, Historia del pensamiento estético árabe, pp. 539, 733, 736, 755 note 32) the Light Verse both at the beginning "God is the Light of the heavens and the earth" (Qur'ān, 24:35) and at the end "God directs His Light towards whoever He wishes" leaves itself open to allocating to light symbolic interpretations of a religious nature.

${ }^{56}$ Muñoz Sendino, La escala de Mahoma, quoted by Cabanelas Rodríguez, El techo del salón de Comares en la Alhambra, p. 86. 


\section{Bibliography}

Almagro, A., "La documentación planimétrica de los monumentos de Sevilla inscritos en la lista del Patrimonio Mundial," Apuntes del Alcázar de Sevilla, 14 (2013), pp. 72-91.

Almagro, A., "Sistemas constructivos almohades: estudio de dos bóvedas de arcos entrecruzados," in S. Huerta, I. Gil Crespo, S. García and M. Taín (eds.), Actas del Séptimo Congreso Nacional de Historia de la Construcción, Santiago 2629 octubre 2011, Madrid, Instituto Juan de Herrera, 2011, pp. 45-53.

Almagro Gorbea, A., Soler Estrela, A. and Soler Verdú, R., "La torre almohade de Villena (Bilyana) y sus bóvedas de nervios entrecruzados. Análisis formal y constructivo," Anales de Historia del Arte, 24 (2014) (en prensa).

Berbrugger, A., Algérie historique, pittoresque et monumentale : recueil de vues, monuments, cérémonies, costumes, armes et portraits, dessinés d'après nature, avec texte descriptif des localités, mours, usages, jeux et divertissements des habitants de l'Algérie, Paris, J. Delahaye, 1843.

Bourouiba, R., L'art religieux musulman en Algérie, Alger, SNED, 1973.

Brosselard, C., "Les inscriptions arabes de Tlemcen (1)," Revue africaine, 14, décembre (1858), pp. 81-94.

Cabanelas Rodríguez, D., El techo del salón de Comares en la Alhambra. Decoración, policromía, simbolismo y etimología, Granada, Patronato de la Alhambra y el Generalife, 1988.

Cabañero Subiza, B. y Herrera Ontañon V., "Nuevos datos para el estudio de la techumbre de la ampliación de al-Hakam II de la mezquita aljama de Córdoba: cuestiones constructivas," Artigrama, 16 (2001) pp. 257-283.

Camps Cazorla, E., Modulo, proporciones y composición en la arquitectura califal cordobesa, Madrid, CSIC, 1953.

Charpentier, A., "Tlemcen et l'évolution des modèles de l'architecture religieuse au Maghreb," L'homme et la société, 6 [Août] (2013), pp. 139-150.

Charpentier, A. (dir.) and Terrasse, M. (col.), L'image de Tlemcen dans les archives françaises. Catalogue de l'exposition Tlemcen 2011, [Algérie], Tlemcen, 2011.

Ewert, Ch., Spanisch-Islamische Système sich Kreuzender Bögen. III Die Aljafería in Zaragoza, 1. Teil-Text, Berlin, Walter de Gruyter \& Co, 1978.

Fernández Puertas, A., Mezquita de Córdoba. Su estudio arqueológico en el siglo XX, Granada, Universidad de Granada-Universidad de Córdoba, 2009.

Golvin, L., "Quelques réflexions sur la Grande Mosquée de Tlemcen," Revue de l'Occident musulman et de la Méditerranée, 1, $1^{\mathrm{er}}$ semestre (1966), pp. 81-90.

Gómez Moreno, M., "El Arte árabe español hasta los almohades. Arte Mozárabe," in Ars Hispaniae, v. III, Madrid, Plus Ultra, 1951.

Hoag, J.D., Arquitectura Islámica, Madrid, Aguilar, 1976. 
López Guzmán, R., Arquitectura mudéjar, Madrid, Cátedra, 2000.

Marçais, G., Album de pierre, plâtre et bois sculptés, fasc. 1 y 2, Art Musulman d'Algérie, Alger, Typographie-Lithographie Adolphe Jourdan, 1909.

Marçais, G., L'architecture musulmane d'Occident: Tunisie, Algérie, Maroc, Espagne et Sicile, Paris, Arts et métiers graphiques, 1954.

Marçais, G., Manuel d'art musulman: l'architecture, Tunisie, Algérie, Maroc, Espagne, Sicile, Paris, Auguste Picard, 1926-1927.

Marçais, W. and Marçais, G., Les monuments arabes de Tlemcen, Paris, Fontemoing, 1903.

Meunié, J., Terrasse, H. and Deverdun, G., Nouvelles recherches archéologiques à Marrakech, Paris, Arts et métiers graphiques, 1957.

Muñoz Sendino, J., La escala de Mahoma, traducción del árabe al castellano, latín y francés ordenada por Alfonso X Rey de Castilla; Ed. crítica, introducción y notas por J. Muñoz Sendino, Madrid, Dirección General de Relaciones Culturales, 1949.

Navarro Palazón, J. and Jiménez Castillo, P., "La arquitectura de Ibn Mardanish: Revisión y nuevas aportaciones," in G. M. Borrás Gualis and B. Cabañero Subiza (coords.), La Aljafería y el Arte del Islam Occidental en el siglo XI, Zaragoza, Institución Fernando el Católico, 2012.

Papadopoulo, A., El Islam y el Arte musulmán, Barcelona, Gustavo Gili, 1977.

Puerta Vílchez, J. M., Historia del pensamiento estético árabe. Al-Andalus y la estética árabe clásica, Madrid, Akal, 1997.

Terrasse, H., La grande mosquée al-Qaraouiyin à Fès, Paris, Librairie C. Klincksieck, 1968.

Terrasse, H., La grande mosquée de Taza, Paris, Les éditions d'Art et d'Histoire, 1943.

Terrasse, M., L'esthétique tlemcénienne et son évolution: signes d'échanges méditerranéens," L'homme et la société, 6 [Août] (2013), pp. 241-256.

Torres Balbás, L., "Bóvedas caladas hispanomusulmanas," Al-Andalus, XVII, 1 (1952), pp. 186-199.

Recibido: $19 / 09 / 2014$

Aceptado: 16/02/2015 